\title{
Teorías de la metáfora: ¿relación o propiedad*?
}

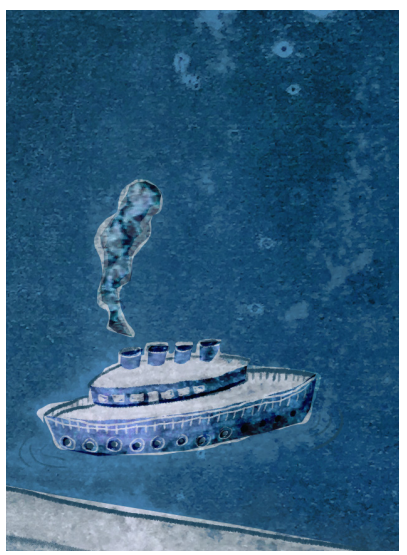

José Seoane Seoane

Universidad de la República - Sistema Nacional de Investigadores

seoanejose2010@gmail.com

\author{
Andrés De Azevedo Horta \\ Universidad de la República \\ aazevedo@vera.com.uy
}

\section{Resumen}

Este artículo intenta explorar estructuralmente diversas teorías de la metáfora en términos de la oposición relación-propiedad. Esta perspectiva arroja como resultado una clasificación (gradualista) entre teorías relacionales y teorías propietales. Dada la indiscutida importancia histórica y analítica de las primeras, nos hemos concentrado en algunos ejemplos emblemáticos: las perspectivas aristotélica, interaccionista y cognitiva. Brindamos una justificación breve de la comprensión de tales teorías como relacionales y una descripción sucinta de las respuestas que cada una de ellas ofrece a dos desafíos fundamentales: la identificación del campo de la relación metafórica y los rasgos que esta relación exhibe en cada caso. El objetivo pretendido por esta exploración conceptual no se reduce, exclusivamente, a la clasificación propuesta; su propósito más general consiste en evidenciar el potencial heurístico de tal enfoque estructural.

\section{Metaphor theories: relation or property?}

\begin{abstract}
This article attempts to explore structurally the various theories of metaphor in terms of the property-relation opposition. This perspective yields as a result of a provisional (gradualist) classification between relational

* Deseamos expresar nuestro reconocimiento a Virginia Bertolotti, por su estímulo y colaboración en la etapa de elaboración de estas ideas, así como por sus sugerencias y observaciones a una primera versión de este ensayo, que nos permitieron corregir formulaciones y mejorar argumentos. Deseamos también dejar constancia de nuestro agradecimiento a Ana Clara Polakof, por su lectura cuidadosa y aguda, y sus valiosas correcciones y observaciones que nos fueron de gran ayuda. Asimismo, hemos intentado mejorar algunos aspectos a partir de las observaciones valiosas de un árbitro anónimo. Por supuesto, los errores subsistentes son de nuestra exclusiva responsabilidad.
\end{abstract}

Palabras clave

\section{Metáfora}

Teorías de la metáfora

Semántica
Keywords

Metaphor Metaphor Theories Semantics 
theories and proprietal theories. Given the undisputed historical and analytical importance of the former, we have considered some emblematic examples: the Aristotelian, interactionist and cognitive perspectives. We offer a brief justification of the understanding of them as relational and a succinct description of the answers that each of them offers to two fundamental challenges: the identification of the field of the metaphorical relationship and the features that this relationship exhibits in each case. The objective of this conceptual exploration is not limited exclusively to the proposed classification; its more general purpose is to highlight the heuristic potential of such a structural approach.

\section{Resumo}

Este artigo procura explorar estruturalmente as diversas teorias da metáfora em termos da oposição relação - propriedade. Esta perspectiva traz como resultado uma provisória classificação (gradualista) entre teorias relacionais e teorias propietais. Devido a que a importância histórica e analítica das primeiras não têm sido discutida, focamo-nos em alguns exemplos emblemáticos: as perspectivas aristotélica, interacionista e cognitiva. Proporcionaremos uma justificação breve da compreensão das mesmas como relacionais e uma descrição sucinta das respostas que, cada uma de las, oferece para dois desafíos fundamentais: a identificação do campo da relação metafórica e os rasgos que esta relação apresenta em cada caso. $\mathrm{O}$ objetivo desta pesquisa conceptual não se limita, exclusivamente, à classificação proposta; seu objetivo mais geral é destacar o potencial heurístico dessa abordagem estrutural.

\section{Introducción}

La metáfora ha recibido atención casi desde los orígenes de la filosofía - por supuesto, no solo los filósofos han procurado descifrar sus enigmas-: el resultado de tales persistentes desvelos ha sido una abrumadora proliferación teórica. Hoy es difícil orientarse en esa exuberante selva reflexiva y, especialmente, aprovechar crítica y creativamente tal multitud de esfuerzos. Clasificar el campo de las teorías de la metáfora no ofrece una solución directa a tal problema, pero esta operación aparece como prometedora en dirección a ese fin.

Motivados por tal desafío, nuestro punto de partida es la pregunta básica: ¿cómo conceptualizan, abstracta o estructuralmente, las distintas teorías de la metáfora, el fenómeno metafórico? Más específicamente: ¿entienden la metáfora por medio de una propiedad o lo hacen, más bien, a través de una relación? La inclinación por una u otra de las alternativas no siempre resulta absolutamente nítida; pueden, no obstante, apreciarse grados diversos de definición con relación a este dilema estructural (como veremos oportunamente, en algunos casos, la misma es explícita y radical, y en otros mucho menos enfática). Pero el reconocimiento de tal definición provee una clave valiosa a los fines de la comprensión de la teoría considerada en sí misma, así como permite una mejor comparación o contraste interteórico. En particular, conlleva a una clasificación de las teorías en cuestión. El propósito de este artículo es, entonces, más que responder categóricamente al interrogante de su título, argumentar a favor del potencial heurístico de dicha pregunta. Más concretamente, los objetivos son dos: a) proponer una
Palabras-chave

Metáfora Teorias da metáfora Semântica 
forma de análisis estructural (a partir de la polaridad propiedad/relación) que permita comparar y, consecuentemente, clasificar diversas teorías de la metáfora; y b) mostrar cómo la opción estructural ilumina la arquitectura específica de cada teoría (concentrándonos exclusivamente, por su extraordinaria influencia, en las teorías relacionales).

La estructura de la exposición es la siguiente: la sección 2 introduce la distinción entre teorías relacionales y teorías propietales de la metáfora, dependiendo de cómo las mismas modelan el fenómeno metafórico, entendiéndolo, respectivamente, como relación o como propiedad; la sección 3 visita, sucintamente, diferentes teorías de la metáfora y esboza una primerísima clasificación de estas en términos de la polaridad presentada en 2 -se procura allí revisar, en forma estilizada, algunas formulaciones teóricas muy influyentes-; las secciones 4 y 5 responden a dos cuestiones que, necesariamente, deben enfrentar las teorías relacionales: ¿qué tipo de entidades son las relacionadas?, y ¿qué rasgos exhibe la relación metafórica?; a la luz del comportamiento de las teorías estudiadas respecto de tales cuestiones, la sección 6 revisa la clasificación anterior, retomando no solo la descripción más o menos explícita que cada teoría propone del fenómeno metafórico, sino su coherencia y profundidad estructural; la última sección propone combinar el eje relacional-propietal con el eje conceptual-expresivo -fruto de la discusión desarrollada en 4- para brindar una percepción más completa de las teorías discutidas, a la vez que sugiere un conjunto de cuestiones dignas de estudio (se espera que estas contribuyan a persuadir al lector del interés de la perspectiva estructural defendida).

\section{Teorías de la metáfora: ¿relación o propiedad?}

"Propiedad” y "relación” se entenderán aquí en un modesto sentido lógico, desprovisto de cualquier tipo de pretensión filosófica profunda. "Propiedad" querrá decir simplemente 'aquella condición o característica expresable a través de un predicado unario'; “relación” se referirá a 'aquel vínculo o articulación expresable mediante un predicado binario'. Así, podemos hablar de la propiedad de "ser un número natural" y de la relación "es el sucesor de"; a los efectos de hacer visible la diferencia de aridad (unario el primero, binario el segundo) podemos retratar tales predicados así: “...es un número natural”, “...es el sucesor de...”. Desde el punto de vista sintáctico, los puntos suspensivos se sustituyen por términos del lenguaje. Desde el punto de vista semántico, estos tipos de predicados se interpretarán de forma estructuralmente diversa; si, como es habitual, pensamos su interpretación en términos conjuntísticos, el primer tipo requerirá subconjuntos del dominio de interpretación, y el segundo demandará conjuntos de pares ordenados (cuyas proyecciones serán elementos del dominio).

Entenderemos las teorías o perspectivas acerca de la metáfora como esfuerzos intelectuales orientados a caracterizar, tomada esta última expresión en su sentido más hospitalario, cierta clase de objetos, entendidos éstos en un sentido puramente metodológico ${ }^{1}$. ¿Cuáles objetos? La respuesta es obvia: las metáforas. Podríamos denominar Obj al conjunto conformado por estas. La pregunta que nos formulamos, entonces, es, desde un punto de vista estructural, ¿cómo captar los elementos de Obj? Dado que tenemos una aproximación preteórica a estos objetos (prueba de ello es que usamos la palabra "metáfora" previamente al trato con las diversas teorías de la metáfora) quizás sea conveniente distinguir la pregunta recién formulada,
1. Por razones de comodidad expresiva, adoptaremos la expresión "teoría de la metáfora" para referirnos a las reflexiones sobre tal fenómeno, más allá del nivel de sistematización que las mismas revistan. Seguimos en este sentido una práctica muy extendida, sin que esto suponga un juicio sustantivo acerca de la conveniencia o pertinencia de usar "teoría" para catalogar esfuerzos teóricos cuyos niveles de estructuración pueden resultar extremadamente laxos. Para una categorización de tipos de teorías consistente con tal práctica ver de Azevedo (1997). 
de aquella que tiene por cometido averiguar la naturaleza estructural de la aproximación preteórica. Dicho de otra forma, podríamos distinguir dos conjuntos: el conformado por los objetos de la reflexión preteórica (Objpt) y el integrado por los objetos de la reflexión teórica (Objt). La pregunta que queremos formular es, entonces, qué significa pertenecer —desde el punto de vista estructural- a Objt, y no qué significa hacerlo respecto a Objpt. Esta última pregunta posee, sin embargo, un contenido valioso desde nuestro punto de vista: se trata de esclarecer aspectos estructurales de la noción intuitiva. Entre otros aspectos, si pudiésemos encontrar una respuesta satisfactoria a tal enigma, estaríamos en condiciones de analizar continuidades y rupturas de las aproximaciones teóricas respecto de las aproximaciones preteóricas. Este ensayo no ingresará en esta cuestión, pero, reiteramos, no por considerarla impertinente o asignificativa ${ }^{2}$. El objeto de la reflexión que proponemos comprende, en este respecto exclusivamente, a la noción teórica, cuya justificación deriva del objetivo antes establecido.

La pregunta central, entonces, es si el enfoque teórico caracteriza la metáfora por medio de una propiedad (dicho rápidamente: $x$ es una metáfora si y solamente si $P M y$, donde puede ocurrir $x=y$ ) o si lo hace a través de una relación (dicho esquemáticamente: $x$ es una metáfora si y solamente si $R M y z$, pudiendo ocurrir $x=y$ ). El lector advierte que, si $x=y$, tal referencia aparece a ambos lados del bicondicional; en cualquier caso, la formulación general evidencia, nítidamente, que lo que se pretende captar es la estructura de la explicación propuesta (propietal/relacional). Podría entonces hablarse en un sentido muy natural de propiedad metafórica $(P M)$ o de relación metafórica $(R M)$. Por supuesto, pueden advertirse estrategias de "traducción" relativamente inmediatas orientadas a trasladar una caracterización desde un formato al otro. Pero el punto aquí no es la irreductibilidad de las opciones, sino cuál es la alternativa asumida por una teoría específica y cuáles son las consecuencias estructurales, en dicha teoría, de tal asunción.

¿Cuán explícita o transparente es una teoría respecto de su opción estructural? Este interrogante puede entenderse en un sentido puramente retórico: ¿cuán manifiestamente plasman su opción estructural los autores de la teoría? Pero este no es el único punto que nos interesa. Además, pretendemos discutir interrogantes tales como: ¿cuán coherentes son otras decisiones al interior de la teoría con la opción estructural escogida?, y ¿qué tan estructuralmente consistente es una teoría? Estos desafían una comprensión más fina de las diversas perspectivas o puntos de vista teóricos. Tal indagación estará en el centro de nuestro interés.

Resulta entonces útil imaginar dos modelos ideales como polos de un eje continuo. La ubicación de las diversas teorías concretas, de acuerdo con su cercanía respecto de uno u otro polo, permitirá una visualización rápida de su definición estructural.

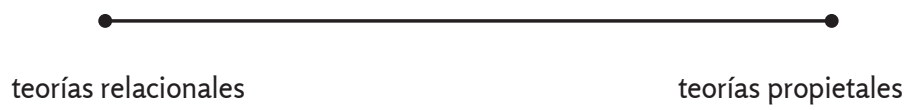

Figura 1

Como se expuso, al igual que existen diferentes grados de explicitación de la estructura relacional, también existen grados diferentes de incidencia
2. El contraste entre concepto preteórico/concepto teórico ha sido introducido cuidadosamente en relación con la noción de elucidación matemática (Seoane 2017) y, especialmente, la defensa del valor de la discusión elucidatoria en términos de enriquecimiento conceptual y comprensión histórica (restringidos al campo de las matemáticas) ha sido explicitado en Seoane (2003 y 2017); sospechamos es posible extender tal vindicación (respetando las especificidades correspondientes) a otras áreas del conocimiento. 
o impacto de la dicha estructura en la organización teórica de las distintas concepciones de la metáfora. Parece razonable asumir, luego, un eje continuo como forma de representar tal situación; la localización en el eje indicará (en forma aproximada) el grado en que la elección estructural básica (propietal, relacional) organiza o conforma la teoría en cuestión. Nótese que la ubicación no procura retratar el nivel de explicitud en la formulación de la alternativa estructural, sino el grado o fuerza de esta última como factor articulador de la propuesta teórica.

\section{Clasificando teorías: una primera aproximación}

El propósito de este apartado es describir —esquemáticamente- algunas teorías estelares y explorar a qué "entorno de proximidad" pertenecerían con relación a los polos identificados en la Figura 1. Para tal análisis, hemos elegido representantes emblemáticos de las principales orientaciones teóricas, en un recorrido que comienza con uno de los primeros enfoques sistemáticos más influyentes - como fue el de Aristóteles-y que contempla, además, algunas de las posiciones prevalecientes en la discusión de la figura en el siglo XX y XXI, como son la teoría interaccionista de I. A. Richards y Max Black, el enfoque pragmático de Donald Davidson, y el cognitivista de la Teoría de la Metáfora Conceptual (TMC) inaugurado por Lakoff y Johnson.

\subsection{La concepción sustitutiva de Aristóteles}

El primer texto teórico de peso en la historia de la reflexión sobre la metáfora elabora un planteo de carácter relacional. Las siguientes consideraciones pretenden justificar esta afirmación.

Aristóteles considera a la metáfora como un elemento caracterizador de dos tipos de uso de lenguaje. Por un lado, es una "herramienta" (estrategia discursiva) que sirve para la persuasión en el campo retórico; por el otro, un elemento que sirve para el desarrollo de la finalidad mimética de componer una representación, esencial de las acciones humanas, en el campo poético. Tanto en la Poética como en la Retórica, la metáfora es presentada como procedimiento de la elocución (lexis), la cual comprende el plano de la expresión e incluye la "acción oratoria" (uso de la voz). La indagación sobre cómo hay que decir lo que se quiere decir exhibe la función persuasiva de la elocución. En el campo poético, entre tanto, la elocución es uno de los medios disponibles de imitación por medio del lenguaje (Poética, 6, 1449b 24-31). Para una presentación general de ambos tratados y su vínculo con la metáfora, remitimos a Ross (1923), Ricoeur (1975), Díaz Tejera (1995) y Kirby (1997).

Estructuralmente, la metáfora es caracterizada como "la traslación de un nombre ajeno, o desde el género a la especie, o desde la especie al género, o desde una especie a otra especie, o según la analogía" (Poética, 21, 1457b 6-9). Esta caracterización deja entrever, entre otras cosas, una suerte de tipología que la tradición se ha encargado de cuestionar. Ocurre que algunas de las posibilidades entrevistas se acomodan mejor a otros procedimientos retóricos, como la sinécdoque (Bobes 2004, Eco 1990, Femenías 1998, Gambra 1990, Marcos 1997). La interpretación prevaleciente tiende, en consecuencia, a rescatar la importancia de la cuarta opción, la de la analogía, que el propio autor se encargó, por otra parte, de resaltar (cf. Retórica 1405a 9 y 1411a 1 s.). 
Aristóteles la presenta en los siguientes términos:

Entiendo por analogía el hecho de que el segundo término sea al primero como el cuarto al tercero; entonces podrá usarse el cuarto en vez del segundo o el segundo en vez del cuarto; y a veces se añade aquello a lo que refiere el término sustituido (Poética, 21, 1457b 17-20).

Dada la expresión:

(1) La vejez es el ocaso de la vida;

se establece una relación proporcional, según la cual, la vejez es a la vida como el ocaso al día, donde puede percibirse el establecimiento de una igualdad de razones (o proporciones) que comporta cuatro términos (A/B, C/D), y donde se confronta el primer par con el segundo (vejez/vida, ocaso/día).

La propia definición de la metáfora como procedimiento que consiste en dar a una cosa el nombre de otra, junto con los ejemplos que acompañan cada una de las posibilidades y, fundamentalmente, el propio recurso de la analogía, evidencian un enfoque relacional. La "mecánica" del procedimiento metafórico, en el sentido del vínculo sugerido entre dos nombres, es un indicio de tal carácter estructural. Esta observación, asimismo, permite sostener que lo característico del planteo aristotélico es el acento puesto en el soporte lingüístico, más específicamente, nominal. Ello pauta una diferencia, como veremos, con otros enfoques. En palabras de Bustos: "Aristóteles parecía pensar que una expresión metafórica operaba una forma de traslado o desplazamiento. Ese cambio era un cambio lingüístico, un cambio de denominación" (de Bustos 2000, 35, cursivas nuestras).

$\mathrm{Al}$ referirse a la traslación de un nombre ajeno, entonces, lo que Aristóteles tiene en mente es el empleo de términos y, particularmente, el fenómeno de la desviación, que resulta del tener que recurrir a expresiones raras, poco frecuentes (rebuscadas, poéticas) y que se oponen a la "usual". Como señala Ricoeur, "la metáfora es entonces doblemente extraña: porque hace presente una palabra tomada de otro campo, y porque sustituye una palabra posible, pero ausente" (Ricoeur 1975, 33). A la necesaria desviación se suma la idea de préstamo, dado que sería posible operar una sustitución con el término propio. De existir alguna duda sobre el indicio relacional, la apelación a la sustitución la disipa absolutamente.

La sustitución, a su vez, abre el juego a la posible reversibilidad denotacional: "el proceso sería reversible: el nombre metafórico podría ser sustituido a su vez, sin pérdida de valor referencial, por el nombre usual" (de Bustos $2000,41)$. Es decir, si se asocia fuertemente el conocimiento a la "novedad" denotacional, es esperable que se asuma la reversibilidad referida como una señal clara del escaso aporte cognitivo de la metáfora ${ }^{3}$. Estos lineamientos serán determinantes para el desarrollo de la concepción ornamental de la figura, tal como la desarrolla la retórica clásica.

No debiera pasar desapercibido que el planteo de Aristóteles se funda sobre la base de una ontología ya dada, sobre la cual la metáfora opera sin modificarla ni innovarla. "La metáfora aparece en un orden ya constituido por géneros y especies, y en un juego de relaciones ya determinadas: subordinación, coordinación, proporcionalidad e igualdad de relaciones" (Ricoeur 1975, 36). Es en este escenario que cobra fuerza el papel de la
3. Sin embargo, algunos autores han reivindicado dicho valor en el marco aristotélico. Precisamente, es tal diferencial el que permite discriminar fundadamente entre metáfora y símil. Véase, por ejemplo, de Bustos (2000, 47). Sobre metáfora y símil en Aristóteles puede verse también Ricoeur (1975), Tamba-Mecz y Veyne (1979), Díaz Tejera (1995) y Kirby (1997) 
semejanza que subyace a todo el planteo. El nombre "ajeno" ha de tener alguna suerte de semejanza con aquel al cual sustituye. Aristóteles señala que "lo más importante con mucho es dominar la metáfora. Esto es, en efecto, lo único que no se puede tomar de otro, y es indicio de talento; pues hacer buenas metáforas es percibir la semejanza" (Poética, 1459a 5-10). La relevancia del papel de la semejanza estuvo presente desde un comienzo en la caracterización de la metáfora por analogía, la única que se apoya en la relación explícita entre dos términos y cuyo análisis reclama "descubrir una identidad o una similitud entre dos relaciones" (Ricoeur 1975, 39). El ejemplo en la Poética es "La copa es el escudo de Dioniso": la relación analógica pretendida es que la copa es a Dioniso como el escudo es a Ares. Las posibilidades entrevistas por Aristóteles en su definición de la analogía consisten, para el caso, en que tanto es la copa el escudo de Dioniso como el escudo la copa de Ares. De allí resulta la posibilidad de construir junto con (1), (1') El ocaso es la vejez del día. Retomaremos esta cuestión en la sección 5.

En síntesis, parecería que existen en la teoría aristotélica dos planos de evidente estructura relacional: un plano lingüístico, donde se describe el fenómeno metafórico en clave de "sustitución", y un plano semántico, donde se encuentra la legitimidad de la operación sustitutiva, a saber: la semejanza de lo denotado por los nombres involucrados en la sustitución. Resulta obvio que la primera caracterización relacional (sustitución) se fundamenta en la segunda (semejanza). Es el papel otorgado por el filósofo a la relación de semejanza lo que posibilita catalogar como sustantivamente relacional al enfoque aristotélico. No obstante, quizás convenga retener esta doble descripción y, especialmente, su articulación.

A riesgo de estilizar en demasía la situación, permítasenos hacer visible la misma a través de la figura siguiente -donde Nom1, Nom2 representan los nombres involucrados, Den1, Den2 las denotaciones respectivas, RSus representa la relación de sustitución y RSem la relación de semejanza; las flechas "finas" verticales la relación de denotación; la flecha "gruesa" vertical la relación de fundamentación; y la flecha horizontal procura representar cómo la economía del lado izquierdo de la figura explica la economía del lado derecho-:

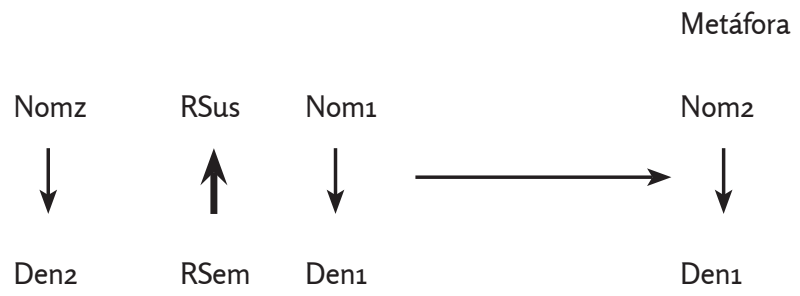

Figura 2

En primer término, hay dos nombres tal que el 2 sustituye al 1, originalmente denotando sendas referencias distintas. Así, en el caso del ejemplo (1), ocaso sustituye a vejez, siendo la denotación del primero, la puesta del sol al trasponer el horizonte y, también, la decadencia, declinación, acabamiento ${ }^{4}$ y del segundo la senectud. Pero la sustitución (metafórica) produce una peculiaridad extraordinaria: iel nombre 2 denota lo que denota el 1 ! Ocaso denota senectud. Y solo puede producirse tal efecto en virtud de la relación entre las denotaciones respectivas, a saber: Den2 es semejante a
4. Cf. primera y tercera acepción de ocaso según el Diccionario de la lengua española de la Real Academia Española y ASALE (DLE [en línea]). 
Den1. En el caso de (1), la base de la semejanza, el cierre de un ciclo, parece incluso estar contemplada por la segunda de las acepciones de ocaso mencionadas.

Adviértase cómo, en el enfoque aristotélico, se vuelve transparente la "doble extrañeza" propia de la metáfora referida anteriormente por Ricoeur: Nom2 denota Den1 y la denominación "posible" (Nom1) se encuentra "ausente" por efecto de la sustitución (Nom2). Siguiendo con el ejemplo (1), ocaso denota senectud y la denominación posible (vejez) está siendo sustituida por ocaso. La articulación entre RSus (la relación de sustitución) y RSem (la relación de semejanza) resulta así establecida en esta perspectiva auroral de la metáfora: RSem fundamenta y explica el papel de RSus. La Figura 2 evidencia el carácter relacional acordado a la metáfora en esta perspectiva, pero, además, resulta especialmente útil para las consideraciones que siguen, referidas a las teorías relacionales que sucedieron temporalmente al enfoque aristotélico.

\subsection{El interaccionsimo de I.A. Richards y Max Black}

El planteo de Richards (1936) y Black (1962, 1979a, 1979b) se inscribe como un desarrollo de la posición romántica (Wordsworth, Coleridge, Shelley $)^{5}$, según la cual la metáfora, recuperando un estatus netamente conceptual, ilumina ciertas zonas de la realidad (produce conocimiento) y permite avizorar relaciones que de otro modo no podrían ser percibidas.

Subyace al planteo de Richards la idea de que el pensamiento es irreductiblemente metafórico, siendo las metáforas lingüísticas meras manifestaciones externas de tales procesos. El autor inscribe la consideración de la metáfora en el universo de una retórica reformada, que tiene por objeto el análisis filosófico de cómo las palabras operan en el discurso. Señala Richards que "cuando utilizamos una metáfora tenemos dos pensamientos de cosas distintas en actividad simultánea y apoyados por una sola palabra o frase, cuyo significado es la resultante de su interacción" (1936, 93, trad. nuestra).

Oponiéndose a una inscripción meramente verbal de la metáfora, Richards resalta que esta es "un préstamo y una relación entre pensamientos, una transacción entre contextos” (ibíd., 94, trad. nuestra), en el marco de una concepción según la cual "el pensamiento es metafórico y procede por comparación, y las metáforas del lenguaje derivan de ahí” (ibíd., trad. nuestra). Un planteo que, salvando la referencia a la comparación, será cabalmente refrendado por TMC.

La síntesis entre pensamientos es la que conforma una metáfora. Richards habla del tenor (la idea subyacente) y el vehículo (la idea prestada, aquella con la que se compara al tenor). "En muchos de los usos más importantes de la metáfora, la co-presencia del vehículo y el tenor da lugar a un significado (que debe ser claramente diferenciado del tenor) al que no se llega sin su interacción" (ibíd., 100, trad. nuestra). Se trata, sin embargo, de una relación que, en principio, no está nivelada; uno de los pensamientos se describe con los rasgos del otro: "podemos describir o clasificar al tenor mediante la descripción del vehículo" (ibíd., 99, trad. nuestra). La interacción de las dos ideas se da en base a un fundamento (ground) compartido y fundado, preferentemente, en la semejanza. De forma estilizada, la perspectiva de Richards podría capturarse en un diagrama como el siguiente, donde Semv y Semt denotan, respectivamente, semántica vehículo y semántica tenor;
5. Para la importancia de tal tradición en la teorización sobre la metáfora ver Vianu (1957) y Bobes (2004, 39-50). El vínculo de Black con dicha orientación ha sido señalado por múltiples autores, entre ellos Kittay $(1987,6)$ y de Bustos (2000,59). Coleridge influyó de manera directa en Richards (1936), quien incluso escribió un tratado sobre él (cf. Ricoeur 1975, 117 n.31). 
y $R I$ la relación de interacción; las flechas verticales la relación expresiva entre el nivel lingüístico y el semántico; y la horizontal, igual que en el caso de la Figura 2.

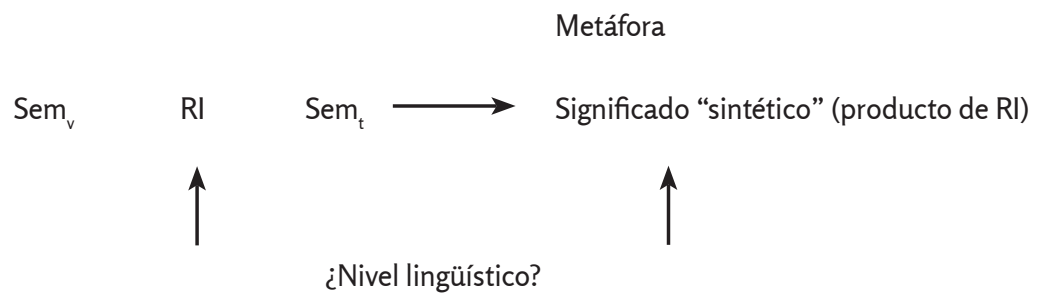

Figura 3

Así, para el caso de:

(2) El hombre es un lobo.

El vehículo lobo entraría en interacción con el tenor hombre, para producir un nuevo significado derivado del "préstamo y una relación entre pensamientos" (Richards, op.cit., 94). El fundamento, entre tanto, estará conformado por una serie de características comunes (como la inclinación a la violencia, la ferocidad, etc.).

La Figura 3 permite apreciar de manera inmediata la primacía del plano semántico. La metáfora es un nuevo significado resultante, precisamente, de esa relación existente entre dos "ideas" $(R I)$, cuya fundamentación radica en la relación de semejanza. El plano lingüístico permanece relativamente en la sombra.

El propósito explícito de Black (1962), por su parte, es avanzar en la mejor comprensión de la naturaleza o función de las metáforas en el lenguaje natural. Aunque toma distancia de la terminología de Richards, en particular, procurando superar la ambigüedad del alcance de los términos tenor y vehículo (cf. 1962, 56, n.23), y planteando, a su vez, discrepancias con el criterio delineado para el fundamento, es indudable que comparte con él lo esencial de la caracterización del fenómeno metafórico, i.e.: la metáfora como producto de cierta clase de interacción conceptual. Corresponde, asimismo, resaltar una coincidencia metodológica muy importante: debe considerarse todo el enunciado para poder extraer la modificación de sentido operada por la palabra.

Para Black, la llamativa "división de trabajo" entre el sentido del enunciado y el de la palabra en cuestión es el primer rasgo característico de la metáfora.

En general, cuando hablamos de una metáfora relativamente sencilla nos referimos a una oración - o a otra expresión- en que se usen metafóricamente algunas palabras, en tanto que las demás se empleen en forma no metafórica... (Black 1962, 38) ${ }^{6}$.

De dicha caracterización, se desprende la posibilidad de aislar la palabra metafórica - el foco- del resto de la frase —el marco-. El mérito de esta terminología, en comparación con la de Richards, es que circunscribe su uso al campo concreto de las expresiones verbales.

6. La afirmación, que adolece de una peligrosa circularidad dado que para definir la metáfora se recurre a "usos metafóricos", es de alguna manera corregida en Black (1979a) mediante el recurso de referirse a "aserciones metafóricas" y "componentes de la aserción” (cf. op.cit., 24, trad. nuestra). 
En el terreno del lenguaje, el planteo de Black (1962) se inclina por procurar aislar la metáfora de su expresión, enfatizando el nivel semántico implicado. Black orienta su mirada hacia una "gramática lógica" de la metáfora y explícitamente señala que "llamar a una frase un ejemplar de metáfora es decir algo acerca de su significado, no sobre su ortografía, su estructura fonética ni su forma gramatical" (ibíd., 39). Esta sugerencia metodológica de énfasis semántico no impide que su enfoque se abra hacia consideraciones de corte pragmático. A tal respecto, señala que "en cierto sentido, 'metáfora' pertenece más a la 'pragmática' que a la 'semántica': sentido que puede ser uno de los más merecedores de atención" (ibíd., 41). Ya que, si bien en algunos casos la metáfora es reconocible por su mera forma, la mayoría de las veces hay que tomar en consideración la ocasión en que se emplea y los pensamientos, actos, sentimientos e intenciones del hablante en el momento de su emisión. En un trabajo posterior, Black (1979a), adscribe sin más su enfoque a la pragmática.

La interacción de ideas de Richards se convierte para Black en la idea de que el foco obtiene un nuevo significado fruto del contexto. Tal significado

no es del todo ni el significado de sus usos literales ni el que podría tener un sustituto literal cualquiera: el nuevo contexto (el 'marco' de la metáfora, en mi terminología) fuerza a la palabra focal a una extensión de su significado (Black 1962, 48-9).

Dicha extensión del significado es explicada mediante el recurso a un "sistema de tópicos" acompañantes del foco, luego llamado "complejo de implicaciones" (Black 1979a). La idea es que el asunto subsidiario (el tópico, o vehículo de Richards), al ser aplicado al asunto principal, lo es con referencia a un conocimiento asociado al sistema de creencias normales del hombre de la calle. Se supone que estos sistemas de lugares comunes son relativamente uniformes y estables en una cultura dada y la eficacia de ellos no pasa por su grado de veracidad (pueden contener "medias verdades" y "crasos errores"), sino por la posibilidad de ser fácil y libremente evocados.

Sólo así es posible llegar al nuevo significado de la metáfora en (2). Para Black, llamar metafóricamente "lobo" al hombre implica evocar un sistema-lobo de tópicos relacionados. Tarea del intérprete será la de seleccionar primero y asociar después cada una de las aserciones implicadas, de modo que se ajusten al asunto principal: "la metáfora del lobo suprime ciertos detalles y acentúa otros: dicho brevemente, organiza nuestra visión del hombre" $(1962,51)$. Organización, selección, supresión y énfasis son algunas de las operaciones a que se somete el asunto principal por efecto de la metáfora.

Ricoeur ve en tal afirmación el rasgo más característico de la metáfora de interacción.

De este modo, la metáfora confiere un insight. La organización de un tema principal por aplicación de otro subsidiario constituye una operación intelectual irreductible, que informa y aclara como ninguna paráfrasis podría hacerlo $(1975,125)$.

Un diagrama puede ayudarnos a visualizar esta conceptualización: 


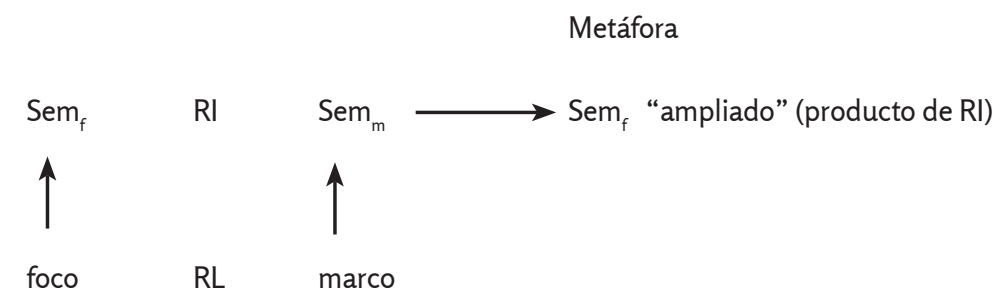

Figura 4

En este caso, se afianza la primacía del plano semántico, donde la metáfora es un significado nuevo resultante, precisamente, de esa relación $(R I)$ existente entre las dos "unidades semánticas": Semf y Semm. Retomando el ejemplo (2), el foco sería "lobo" y el marco "el hombre es" y lo que se daría es una ampliación del significado de "hombre" por selección de aspectos del marco - el asunto principal es el hombre y el asunto subsidiario, el lobo- .

Como se advierte en Black, al igual que ocurría en Aristóteles, la relación "lingüística" o "gramatical" $(R L)$ evidencia la articulación fundamental, la relación semántica $(R I)$. Y, a diferencia de Richards, el plano lingüístico no se difumina al extremo que aparecía en este, pues se encuentra signado (aunque levemente) por aquella relación $(R L)$. Más aún, como el lector advierte, existe en Black un importante refinamiento en la inteligencia de la interacción semántica productiva $(R I)$, cuyo protagonismo había sido identificado por Richards. Nuevamente, el carácter relacional viene asegurado por la presencia estelar de $R I$.

En suma, el interaccionismo conforma un claro enfoque relacional. Aunque el escenario sigue teniendo como marco el lenguaje, en comparación con el planteo aristotélico, se constata un afianzamiento del peso de lo conceptual, ámbito que gana en explicitud. Mientras Richards enfatiza la tensión que resulta del choque de dos ideas, Black (1962) considera que la metáfora opera mediante la aplicación al asunto principal de un sistema de "implicaciones asociadas" característico del asunto secundario. Esta misma idea será expandida en Black (1979a). Allí, se remarca que la aplicación cobra la forma de una proyección. Esta seminal idea ya está presente en Black (1962), cuando compara la metáfora con una pantalla ahumada que deja algunos huecos de visibilidad.

\footnotetext{
Podemos (...) decir que el asunto principal 'se ve a través' de la expresión metafórica —o, si lo preferimos, que resulta 'proyectado sobre' el campo del asunto subsidiario-. (En esta última analogía hay que admitir que el sistema de implicaciones de la expresión focal determina la 'ley de proyección’ (Black 1962, 51, subrayado nuestro).
}

La metáfora organiza los rasgos del asunto primario a través de la proyección de enunciados isomórficos con los miembros del conjunto de implicaciones del asunto secundario. A continuación, veremos cómo esta misma idea se plasma en el contexto cognitivista.

\subsection{El conceptualismo de Lakoffy Johnson y TMC}

El rasgo más notorio del enfoque cognitivista experiencialista de Lakoff y Johnson, con relación a las otras posturas expuestas hasta aquí, consiste en situar de plano la discusión de la figura a nivel del pensamiento, y solo secundariamente en el lenguaje —como veremos más adelante, según esta 
perspectiva, son múltiples los medios o ámbitos en los cuales se pueden corporizar las metáforas. Para dichos autores, iniciadores de TMC, "la esencia de la metáfora es entender y experimentar un tipo de cosa en términos de otra" $(1980,41)$. De lo que se trata, por ende, es de dar cuenta de los patrones regulares, convencionales, de asociación conceptual que rigen el funcionamiento mental, bajo la suposición de que muchos de ellos son de naturaleza metafórica. Quizá resulte útil recordar que TMC entiende por convencionalidad el grado de afianzamiento y sistematicidad de las metáforas conceptuales. Lakoff (1993) argumenta que la proyección conceptual de la mayoría de las metáforas es convencional en el sentido de que "es una parte fijada de nuestro sistema conceptual" (208, trad. nuestra) -cf. Kövecses $(2002,29-32)$ - . Tal orientación explica que presentaciones más recientes de la teoría, como la de Grady $(2007,190)$ sostengan que la noción "más importante" de TMC sea la de la proyección. Por esta, se entiende una correspondencia sistemática entre ideas que cobra la forma de un "mapeo" desde un dominio fuente a un dominio meta, donde el primero es el que proporciona el lenguaje y la imaginería que se utiliza para referir al segundo ${ }^{7}$. El mapeo es la clave explicativa del fenómeno metafórico.

Como es evidente, estas observaciones permiten afirmar, sin temor a equivocarnos, la explícita naturaleza relacional del enfoque; las ideas de "proyección” y "mapeo" remiten hoy, inmediatamente, a la teoría de conjuntos y el uso de las mismas por parte de los autores mencionados se encuentra perfectamente en línea con tal perspectiva teórica. Tal proyección no se reduce a los elementos del dominio fuente respectivos, sino que se proyectan asimismo propiedades, relaciones, etc., que lo caracterizan (cf. Grady, op.cit., 191).

Un asunto especialmente interesante en el planteo cognitivo es el del tratamiento de las expresiones con relación a su metaforicidad, puesto que la postura de TMC difiere notoriamente de los posicionamientos habituales. Lakoff (1993, 203, trad. nuestra) sostiene que el término "expresión metafórica” remite a una expresión lingüística (palabra, frase u oración) "que es la realización de superficie de tal proyección entre dominios". Para Kövecses (2002, 4, trad. nuestra), entre tanto, equivale a "palabras u otras expresiones lingüísticas que provienen del lenguaje o de la terminología del dominio conceptual más concreto" (es decir, del dominio fuente). Así, expresiones como:

(3) a. Tus postulados son indefendibles;

b. Atacó cada punto débil de mi argumento;

c. Sus comentarios dieron en el blanco;

movilizan el léxico, los significados y las implicaciones del dominio fuente (en este caso la GUERRA) para articular el dominio meta (la DISCUSIÓN). Lo que vincula a todas estas expresiones es una metáfora conceptual: UNA DISCUSIÓN ES UNA GUERRA; la que en sí misma difícilmente se exprese ${ }^{8}$, si no es a través de expresiones lingüísticas concretas, que son las que testimonian la presencia de un pensamiento metafórico. Es claro que en TMC las expresiones metafóricas conforman un tipo de evidencia (pero no el único) para la postulación de la existencia de tales metáforas conceptuales.

Comparativamente con los casos de la teoría aristotélica y el interaccionismo de Richards y Black, asistimos a una notoria radicalización en el manejo de los parámetros de la opción estructural. Como vimos, una metáfora
7. La exposición y discusión de TMC en este trabajo (siguiendo la terminología de esta teoría) habla de "dominio fuente" y "dominio meta" o de "dominios" para referirse a ambos; dado que nunca (en tal contexto) se habla de "dominio" sin más, la diferencia terminológica ("dominio", en nuestra terminología, es lo que TMC llama "dominio fuente") no genera ambigüedad alguna.
8. Por convención, TMC refiere las metáforas conceptuales y los dominios respectivos con mayúsculas. 
conceptual comporta, por definición, dos dominios conceptuales y la comprensión de uno de ellos por el otro, lo cual implica su reconfiguración ${ }^{9}$. A diferencia de los otros enfoques relacionales que hemos presentado, hay en TMC una preocupación explícita por especificar la lógica y características de tal operación. La orientación relacional es visible en muchas de las regularidades que pautan la caracterización de las metáforas conceptuales, como son la sistematicidad, la estructuración parcial y la direccionalidad (cf. de Azevedo 1997), sobre las que volveremos en el apartado 5.

Es sintomático, por otra parte, que el reconocimiento de la naturaleza proyectiva de la metáfora se plasme, a su vez, y desde el inicio de TMC, en una distinción tipológica de metáforas conceptuales basada en el criterio de la cantidad de información del dominio fuente que es "mapeada" al dominio meta. En tal sentido, distinguen entre metáforas estructurales, ontológicas, orientacionales y one-shot (cf. Lakoff y Johnson 1980, Lakoff y Turner 1989, Kövecses 2002).

El siguiente diagrama procura retratar esquemáticamente esta perspectiva -donde Semf representa el concepto fuente, Semm el concepto meta, $R P$ la relación de mapeo o proyectiva, y la flecha vertical significa que las expresiones metafóricas “instancian” la metáfora conceptual:

metáfora conceptual

\begin{tabular}{lll}
\hline $\operatorname{Sem}_{\mathrm{f}}$ & $\mathrm{RP}$ & $\mathrm{Sem}_{\mathrm{m}}$ \\
& $\uparrow$
\end{tabular}

expresiones metafóricas

Figura 5

Siguiendo con los ejemplos de (3), la relación de proyección se da entre el dominio conceptual fuente GUERRA y el dominio meta DISCUSIÓN. Los términos lingüísticos relativos a la indefensión (3a), el ataque (3b) y dar en el blanco (3c) testimonian la activación del dominio fuente, así como los relativos a los postulados (3a), los argumentos (3b) y los comentarios (3c) la presencia del dominio meta. La metáfora conceptual UNA DISCUSIÓN ES UNA GUERRA, con su entramado de proyecciones, opera como la justificación de un comportamiento sistemático (lingüístico y no lingüístico).

No resulta exagerado sostener que, en esta perspectiva, la primacía del plano semántico o conceptual es absoluta; la articulación del plano expresivo aparece intencionalmente difuminada. Más aún, cabría decir que, en realidad, ni siquiera podríamos aseverar la exclusividad del soporte lingüístico en relación con la expresión metafórica. Las expresiones metafóricas podrían ser, obviamente, lingüísticas, pero no necesariamente: podría tratarse de "representaciones" en otro medio, por ejemplo, visual, de los contenidos semánticos respectivos. En palabras de Grady:

El énfasis de la Lingüística Cognitiva en esta dimensión conceptual sugiere una perspectiva en la que la metáfora no es un fenómeno inherentemente lingüístico. De hecho, la lingüística cognitiva concibe a las metáforas como patrones de pensamiento que pueden ser expresados por vías no verbales, tales como las imágenes y los gestos (Grady 2007, 108, trad. nuestra).
9. Este escenario conectivo ha sido cuestionado por enfoques posteriores. De TMC derivó una corriente, denominada Blending Theory, que en vez de hablar de reconfiguración de uno de los dominios plantea que la proyección se da en un espacio nuevo, un tercer dominio (Fauconnier y Turner 2002). Se trata de un enfoque más abarcativo, en el que las proyecciones metafóricas son solo un caso más entre otros. 
El independizar la metáfora de su medio de expresión, como resultado de situarla en el pensamiento, está presente desde los inicios del modelo. En Kövecses (2002), se encuentra una enumeración amplia de ámbitos de la experiencia humana en los que las metáforas conceptuales se "realizan", es decir, en los cuales debe reconocerse la presencia del fenómeno metafórico. Entre ellos, la gestualidad, el lenguaje de señas, las imágenes, dibujos, caricaturas, la publicidad, la escultura y la arquitectura, el cine, los mitos, los símbolos, la política y la economía, las prácticas sociales, la literatura, etc.

Esta radicalidad "doble", en relación con la filiación relacional y a la independencia del medio expresivo, lleva a una particularidad notable en la Figura 5: es el único caso donde la metáfora misma es identificada con la relación metafórica.

\subsection{La teoría causal de Donald Davidson}

En su influyente trabajo "Qué significan las metáforas" (1978), Donald Davidson cuestiona la idea de que lo que caracteriza a una expresión metafórica sea la presencia de un significado especial, apropiado a la ocasión y portador de un valor cognitivo, tal como la defiende Black, entre otros. En contraposición, Davidson, al menos según algunas interpretaciones (cf. Rorty 1987, Nogales 1999, 113 y Stern 2000, 45 y sig. entre otros), expone los esbozos de una teoría causal de la metáfora. Así presentado su esfuerzo, pareciera que le corresponde un lugar entre los teóricos relacionales. Pero veamos con más cuidado el punto.

Este filósofo sostiene que las metáforas "significan lo que significan las palabras, en su interpretación más literal y nada más" $(1978,245)$, por lo que es un "error" postular la existencia de un significado adicional y concebir a la figura como "un vehículo para conducir ideas" (ibíd., 246). Así, en el caso de su ejemplo inaugural:

(4) La metáfora es el sueño del lenguaje.

se predica que existe algo como el sueño del lenguaje y que el sujeto de tal predicación, la metáfora, pertenece a ese ámbito.

Conviene detenerse en el estudio de este ejemplo. Podría identificarse aquí, al igual que en los casos de los teóricos anteriormente discutidos, un indicio de adhesión relacional en la mecánica de expresión metafórica. En este caso, tal indicio podría consistir en la predicación. Tomemos una predicación corriente:

(5) El hombre es un animal.

En (5) se aplica a hombre el predicado animal. Esta descripción es adecuada para una frase que se decodifica, llanamente, en términos literales. Ahora bien, ¿qué sucede con el ejemplo (4) de Davidson? Exactamente la misma operación: se aplica a metáfora el predicado el sueño del lenguaje. Por lo tanto, no hay nada extraño en la decodificación de la metáfora hasta aquí. El punto es que este nivel relacional superficial, como resulta de la comparación entre ambas expresiones, no nos dice nada acerca de la metáfora; evidencia, en cambio, lo que posee la expresión metafórica en común, si se quiere, con las expresiones no metafóricas. 
Lo propio de la metáfora está en otra parte: en las expresiones metafóricas, "el significado ordinario en el contexto de uso es lo suficientemente extraño como para urgirnos a dejar de lado la cuestión de la verdad literal" (ibíd., 257). Lo que sucede es que el contexto de uso nos impulsa a descartar la verdad literal y, consecuentemente, a no interpretar literalmente la frase. Es decir, una oración usada metafóricamente expresa un estado de situación que no se corresponde con la realidad, por lo que es usualmente falsa y, luego, nos obliga, en un contexto determinado, a no interpretarla literalmente.

El rechazo a la existencia de un significado metafórico, por parte de Davidson, va de la mano de la defensa de un marco eminentemente pragmático:

Pienso que la metáfora pertenece exclusivamente al dominio del uso. Es algo que se obtiene a partir del empleo imaginativo de las palabras y oraciones y que depende por completo de los significados ordinarios de esas palabras y por lo tanto de los significados ordinarios de las oraciones que ellas abarcan (Davidson 1978, 246).

Ha sido señalado que, al ubicar la metáfora en el ámbito del uso, Davidson articula dos distinciones de modo simultáneo: una que remite a la diferencia entre significado (en tanto noción semántica) y el uso (noción pragmática que implica al lenguaje como herramienta para llevar a cabo ciertas acciones) y otra, relacionada con la anterior, que discrimina los fenómenos determinados por factores semánticos (como el significado) de los fenómenos determinados por cuestiones pragmáticas, a nivel de los usuarios (cf. Nogales 1999, 62). El gesto teórico es claro: la metáfora no estaría determinada por factores semánticos y, por ende, quedaría fuera de un estudio de tal índole.

Como se expresó anteriormente, Davidson defiende una teoría causal, según la cual la metáfora ha de ser explicada en términos de los efectos que provoca. "Una metáfora nos hace prestar atención a alguna semejanza, a menudo una semejanza nueva o sorprendente, entre dos o más cosas" (ibíd., 247, subrayado nuestro),

una metáfora dirige la atención a los mismos tipos de similitud, sino a las mismas similitudes, hacia las cuales la dirige el símil correspondiente. (...) La metáfora y el símil no son más que dos recursos entre los innumerables que sirven para ponernos al tanto de distintos aspectos del mundo, invitándonos a hacer comparaciones (Davidson 1978, 254, subrayado nuestro).

La clave de la metáfora está en la capacidad de orientarnos hacia afuera del lenguaje, "hacia aquello de que trata el lenguaje" (ibíd., 250), en hacernos notar cosas. Pero adviértase que esta capacidad de la metáfora no se encuentra en absoluto articulada con la predicación aludida, de modo que aquel posible indicio relacional se desvanece, en tanto no alcanza a trabajar para ofrecer una clave de comprensión del fenómeno metafórico.

No obstante, podríamos preguntarnos si el recurso a la captación de semejanzas no nos proporciona la base relacional de su enfoque. La captación de la semejanza se aloja en el efecto, es decir, en lo producido por la metáfora, pero ino puede captarse dicha similitud por otras muchas estrategias? Como bien señala el filósofo, la metáfora y el símil no son sino algunos de los múltiples recursos que nos permiten percibir semejanzas. Luego, esta 
captación de semejanza que forma parte del efecto de la metáfora no la caracteriza; en todo caso, muestra lo que tiene en común con otros recursos. Así, la búsqueda de la especificidad de la metáfora, a través de la relación de semejanza, parece condenada al fracaso. Es decir, dada esta situación, tal relación no puede ser la clave estructural del enfoque davidsoniano. Pero, ¿tal clave no la proveerá la relación causal?

Al disponer únicamente de las palabras con su significado literal, ¿̇cómo es que ellas llegan a orientarnos - desde la perspectiva de Davidson- en la dirección de la peculiar captación de la semejanza? Esta cuestión ha sido planteada, de una forma quizá algo equívoca, por Stern (1991, 30, trad. nuestra): ¿Qué tipo de explicación causal se puede dar, acerca de cómo la emisión de la oración literal se relaciona con el rasgo metafóricamente relacionado que posteriormente vemos o notamos? Davidson responde que

\footnotetext{
Una metáfora hace su trabajo por medio de otros intermediarios; suponer que ella sólo puede ser efectiva si conduce un mensaje codificado es como pensar que una broma o un sueño emiten un enunciado que un intérprete lúcido puede reenunciar en prosa Ilana. Como una imagen o un golpe en la cabeza, una broma o un sueño o una metáfora pueden hacernos apreciar un hecho, pero sin representar o expresar ese hecho (Davidson 1978, 26o, subrayado nuestro).
}

El símil del golpe en la cabeza es lo suficientemente gráfico: la metáfora nos hace notar algo - no percibido antes - haciendo, mediante una relación causal, que nos demos cuenta, pero nunca expresándolo como su significado o contenido proposicional. Stern considera que la causalidad en juego es de tipo epistémica, en oposición a una causalidad ontológica capaz de producir la semejanza (como es el caso de Black): "la emisión de la metáfora nos causa o hace notar o reconocer las semejanzas que forman parte de su efecto, o interpretación; más que constituirlas, las deja ver" (op.cit., 28, trad. nuestra).

Son muchos los elementos que facilitan la conclusión de que Davidson reduce drásticamente la pertinencia lingüística de la metáfora, dejándola más próxima a un ruido que a un sonido articulado y dotado de intención comunicativa. Se pueden enumerar al menos seis constataciones de esta orientación de "vaciamiento" semántico de la metáfora, por parte de Davidson, $\mathrm{y}$, consecuentemente, de deflación o pérdida comunicativa: que la metáfora no es "un vehículo para conducir ideas" $(1978,246)$, que no es portadora de un significado especial, que no es parafraseable porque "no hay nada allí para parafrasear" (ibíd.), que cual un bastonazo puede hacernos apreciar un hecho sin tener que representarlo o expresarlo, el escepticismo del autor en cuanto a que la metáfora sea explicable únicamente en términos de significado (cf. 255) y el suspenso decretado en cuanto al valor de verdad de las expresiones metafóricas en tanto metáforas. Si bien no niega su verdad o falsedad, se cuida de señalar que a dicha adjudicación de valores no se llega a través de las oraciones que las contienen (cf., 245 y 255).

A la hora de hacernos notar el rasgo metafórico (o la semejanza), lo único disponible es la emisión en bloque. "Para Davidson la mínima unidad lingüística que constituye 'la metáfora' - aquello que lleva adelante la alerta, estimulación, incitación, etc.- es siempre la oración completa o la expresión emitida en un contexto" (Stern 1991, 29, trad. nuestra). El efecto metafórico lo logra la emisión de la "unidad lingüística" (como una totalidad) en un contexto determinado, por lo que 
así como las imágenes, que en ningún sentido bien definido tienen una sintaxis, las metáforas para Davidson no tienen una "estructura metafórica" interna más allá de la estructura literal, y en tanto metáforas, tampoco hacen uso de su estructura sintáctica o semántica para el logro de tal efecto (Stern 1991, 29, trad. nuestra).

Si se asumiera el punto de vista de Stern y se procurase, entonces, recurrir a ámbitos relativamente naturales (como el sintáctico y el semántico) para encontrar relaciones candidatas a iluminar el fenómeno metafórico, pareciera que tal búsqueda también estaría condenada necesariamente al fracaso.

Siguiendo a Rorty (1987), quien considera que en Davidson la metáfora se aproxima más a un evento natural no familiar que a una cuestión de representación de las palabras, puede afirmarse entonces que la teoría causal facilita y fomenta la pérdida absoluta de la funcionalidad lingüística de las expresiones metafóricas. Si las metáforas son equiparadas a un trueno o a un trino de pájaro, entonces ellas no se diferencian de los eventos no intencionales en lo que hace a su funcionamiento causal -cf. Rorty (1987, 284). De ser así, lo interesante es que

nuestra habilidad para "entender" una metáfora no cae bajo la rúbrica del dominio del lenguaje (independientemente de cual sea nuestra teoría de la competencia lingüística) y cómo la metáfora causa sus efectos tampoco implica ninguna de las propiedades en tanto lenguaje e incluso en tanto especie de acción intencional (Stern 1991, 31, trad. nuestra).

Es decir, que una explicación causal strictu sensu de cómo operan las metáforas contendrá poco o nada de su carácter en tanto uso del lenguaje (o como acto intencional) (cf. Stern, op.cit, 32).

Si esta línea interpretativa es adecuada, entonces la eventual condición de relación causal que conecta la metáfora y sus efectos, no parece ser la clave de comprensión de la primera, al menos, como fenómeno expresivo; parece luego más atinado reconocer el hecho de que, simplemente, cierta expresión produce tales efectos y, consecuentemente, se trata de una metáfora. Dicho de otro modo: al igual que un golpe en la cabeza, la metáfora posee la propiedad de generar ciertos efectos. Lo que la caracteriza es su (peculiar) efecto. En tal sentido, la concepción davidsoniana parecería distanciarse del polo relacional y, en cierta forma, acercarse al polo propietal. Si debiéramos resumir su enfoque en un diagrama, un candidato sería el siguiente, donde $P M$ significa "propiedad metafórica" y Exp una cierta expresión en un contexto dado:

$$
\operatorname{PM}(\operatorname{Exp})
$$

El lector podría dudar de la corrección del análisis previo en cuanto a su capacidad de identificar la estructura de la teoría davidsoniana. Dicho de otro modo: ¿es realmente propietal esta teoría? Quizás la reflexión en torno a algunas de sus interpretaciones más relevantes contribuya a disipar las dudas.

Por ejemplo, en un artículo específicamente dedicado a rebatir la teoría de Davidson, Black (1979b) sostiene que en una interpretación benevolente que no es la suya- el enfoque davidsoniano podría ser alineado en el marco de la teoría de los actos de habla de Austin. Según tal interpretación, quien emplea una metáfora estaría realizando un acto de habla específico, cuya fuerza podría ser claramente expresada mediante alguna fórmula. "Creo 
que aceptaría esto, o algo similar, dado su énfasis reiterado en cuanto a que quien produce una metáfora está usando palabras para 'sacudir', 'sugerir', 'provocar', y demás, más que decir algo" (1979b, 188, trad. nuestra). Sin embargo, acto seguido, Black observa que la cuestión no parece resolverse a nivel ilocutivo:

\begin{abstract}
Las múltiples observaciones de Davidson acerca de los efectos de una metáfora (que actúa como un 'golpe en la cabeza') podrían sugerir que estaría más interesado en lo que Austin llamaría los efectos perlocutivos del discurso metafórico que en cualquier postulación de una fuerza ilocutiva de una emisión metafórica (Black, 1979b, 188, trad. nuestra).
\end{abstract}

La cercanía de la posición de Davidson con la teoría de los actos de habla - una interpretación que dista mucho de ser unánime- ha sido señalada también por Nogales $(1999,114-5)$ y Reimer $(2001,154)$, entre otros. De Bustos $(2000,275-276)$, por su parte, consigna la oscilación del filósofo en cuanto a ubicar lo metafórico entre lo ilocutivo y perlocutivo. Más recientemente, Lepore y Stone $(2010,174)$ y Somodi (2014) optan por una interpretación perlocutiva. La opinión de Black, entre tanto, es que la posición de Davidson es una reformulación de la teoría sustitutiva (en particular, de la comparación), "una que trata a las metáforas como sustitutos perversamente crípticos de los símiles literales" (Black, 190, trad. nuestra).

Adviértase que tales esfuerzos interpretativos parecen echar luz sobre una cuestión sustantiva si se entiende la teoría davidsoniana como propietal. Si una teoría de la metáfora TM es propietal, según se señaló anteriormente (ver 2.), debe proponer una caracterización del fenómeno metafórico a partir de una propiedad $(P M)$. Luego, en términos conjuntísticos, podríamos expresar la situación de la siguiente manera:

$\mathrm{PM}=\{\mathrm{x}: \mathrm{x} \in \mathrm{X}$ y $\mathrm{x}$ cumple tal y cual condición $\}$

Una pregunta inmediata es: ¿cuál es el conjunto $X$ ? Dicho de otra forma, ¿cuál es la naturaleza de los objetos a los que PM se aplica? Esa es, precisamente, la cuestión sustantiva que aquellas interpretaciones, alineadas con la de Black, nos ayudarían a responder: los actos de habla. Esto supone una ganancia notable respecto de nuestro esquema inicial (PM(Exp)), con su sencilla descripción de la naturaleza de los objetos respecto de los cuales la propiedad se predica. Además, las interpretaciones referidas nos ofrecen una respuesta sólida a una segunda cuestión relativamente inmediata.

Nuevamente, puesto el punto en términos generales, si TM es propietal, ¿qué características debe poseer PM? No se trata, meramente, de actos de habla, se trata de actos de habla que producen determinados efectos. Estas últimas especificaciones son las que ocupan sustantivamente a los intérpretes que se inclinan por asociar la teoría de Davidson con la teoría de los actos de habla. Luego, más allá de las opciones interpretativas particulares, puede reconocerse que esos esfuerzos se orientan a resolver nuestra segunda cuestión, a saber, caracterizar la propiedad metafórica.

Si se privilegia, exclusivamente, el nivel perlocutivo o se oscila entre los niveles ilocutivo y perlocutivo, se trata de una discrepancia, precisamente, en la identificación de algunos rasgos decisivos de la propiedad; descifrar su potencial perlocutivo en términos de similaridad contaría como una opción encaminada a esclarecer otro aspecto de aquella. Así, asumir el carácter propietal, estructura la teoría de modo satisfactorio en torno a dos 
cuestiones que, salvo opinión mejor, son precisamente las que desafían a la interpretación y permiten advertir, en forma neta, la originalidad de la propuesta de Davidson. Desde este punto de vista, la ubicación de la teoría de Davidson como propietal parece revelarse decididamente fecunda.

\subsection{Los "entornos de proximidad"}

Vistos los distintos enfoques y a modo de representar la pertenencia a los respectivos "entornos de proximidad", aquellos podrían ubicarse en dos columnas - cuidando de recordar que poseen grados distintos de cercanía con respecto a los respectivos polos ideales-:

$$
\text { Teorías relacionales Teorías propietales }
$$

Aristóteles
Richards
Black
TMC

Figura 6

Esta forma de agrupar las diversas teorías, como es obvio, no refleja comparación alguna entre las teorías pertenecientes a la misma columna, apenas la pertenencia, por así decirlo, a un "entorno de proximidad" al polo respectivo.

La ubicación en el eje representado en la Figura 1, por el contrario, supondría un análisis estructural más profundo de cada una de las teorías y, luego, al menos un esbozo de análisis comparativo de las mismas. Dada la relevancia de las teorías relacionales, ilustraremos, respecto de ellas, en qué consiste tal análisis específico y su consecuente comparación. En pocas palabras: cómo ubicar, de manera razonada, ciertas teorías relacionales seleccionadas en el eje de la Fig. 1. Pero para realizar dicha tarea, es decir, para refinar la comparación teórica, resulta imprescindible explorar más cuidadosamente desde el punto de vista estructural la arquitectura interna de las diversas teorías. Esos aspectos son los que discuten las secciones 4 y 5 .

\section{Teorías relacionales: el status de los componentes}

Una teoría de la metáfora TM, si es relacional, según se señaló arriba (ver 2.), debe proponer una caracterización del fenómeno metafórico a partir de una relación $(R M)$. Se asumió que la misma es binaria por razones de conveniencia comunicativa ${ }^{10}$.

Dada $R M$ binaria entonces puede representársela (como conjunto) así:

$$
\mathrm{RM}=\{\langle\mathrm{x}, \mathrm{y}\rangle: \mathrm{x}, \mathrm{y} \in \mathrm{Cam} \text {, donde } \mathrm{x} \text { se encuentra en tal y cual relación con } y\}
$$

donde Cam es la unión del dominio y el rango de la relación. De aquí surge una pregunta: ¿cuál es el conjunto Cam? Dicho de otra forma, ¿̇cuál es el tipo o la naturaleza de los objetos que $R M$ relaciona?
10. El lector advertirá que los desarrollos que siguen no dependen en modo alguno de la aridad de la relación, pues la naturaleza del problema fundamental es fácilmente generalizable (es decir, en casos donde la aridad fuera mayor que 2). Por otra parte, debe tenerse en cuenta que la modelización parte de un conjunto singular de teorías y su motivación principal es dar cuenta de estas; en todos estos casos la relación puede entenderse naturalmente como binaria. 
He aquí dos respuestas que parecen relativamente inmediatas: a) los objetos relacionados son de naturaleza lingüística; y b) los objetos relacionados son de naturaleza conceptual. Esta dualidad podría captarse también en términos de un par de polos estilizados o ideales: teorías expresivas y teorías conceptuales. Si se quiere pensar la situación diagramáticamente, podríamos imaginar un segundo eje $^{11}$ :

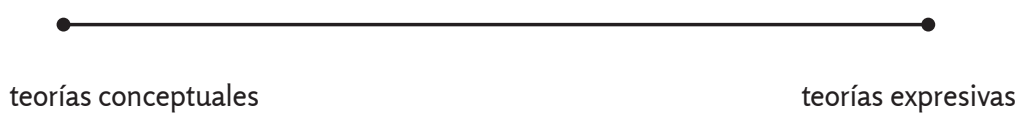

Figura 7

La conveniencia de tal estrategia representacional consiste en captar los diversos grados de proximidad de las distintas teorías respecto de los polos conceptual y expresivo, de modo análogo al caso de la Figura 1. Desde un punto de vista abstracto, podría pensarse que una teoría relacional debiera identificar explícita y precisamente el campo $(\mathrm{Cam})$ y ofrecer una justificación de su pertinencia, pero tal nivel de explicitud no es la regla. ¿Cómo puede ejemplificarse la respuesta a esta exigencia abstracta en los casos específicos antes estudiados?

La posición de Aristóteles parece relativamente neta en relación con la naturaleza de los relacionales: comprende expresiones lingüísticas, más específicamente, expresiones nominales. Se trata, como se recuerda, de la "traslación de un nombre ajeno" (Poética, 21, 1457b 8), por lo que la relación supondría un vínculo entre nombres. El ejemplo (1), arriba discutido, ejemplifica elocuentemente tal observación; más allá de los detalles, podría decirse que la relación metafórica vincula el sustantivo vejez y el sustantivo ocaso (vía el procedimiento ya descripto). Luego, puesto de un modo sintético:

$<\mathrm{v}, \mathrm{o}>\in \mathrm{RM}$

donde $\mathrm{v}, \mathrm{o} \in \mathrm{L}$, más específicamente, $v$, $o$ encarnan los respectivos sustantivos, y $L$ representa el lenguaje.

Pero, como se recuerda, el fundamento de esta relación se encuentra en el nivel denotacional, $i$. e. en la relación de semejanza entre las respectivas denotaciones. Luego, aunque se trata de una relación lingüística, en la intelección de la metáfora importa atender a los nombres en tanto denotadores de objetos semejantes. Y esta restricción excede el plano del lenguaje, pues la semejanza referida no es creada por el lenguaje sino más bien reflejada por él. Así pues, quizá sea razonable asumir que Aristóteles piensa en una relación entre nombres qua denotadores de objetos semejantes y es precisamente la semejanza entre estos (independiente del lenguaje) lo que fundamenta la relación metafórica entre aquellos. En un sentido preliminar, a partir de estas observaciones, debiera ubicarse la teoría aristotélica de la metáfora próxima al polo de las teorías expresivas. Una cuestión interesante es que quizás resulte inmediata o incluso obvia, desde el punto de vista del filósofo, la elección del lenguaje como campo de la relación metafórica.

La situación es muy diferente en Richards. Si se recuerda que, según este autor, "cuando utilizamos una metáfora tenemos dos pensamientos de cosas distintas en actividad simultánea y apoyados por una sola palabra o frase,
11. Por supuesto, tal clasificación tentativa podría aplicarse, con los ajustes correspondientes, a las teorías propietales, es decir, cuál es el tipo 0 naturaleza de los objetos a los cuales se aplica la propiedad metafórica. De hecho, así se hizo respecto del campo de la propiedad metafórica asociada a la teoría de Davidson. Sin embargo, por razones obvias, si se quisiera captar la especificidad de tal campo debería abandonarse la polaridad expresión/concepto, altamente rendidora en el análisis de las tres teorías relacionales que aquí se estudian. 
cuyo significado es la resultante de su interacción" (1936, 93, trad. nuestra), podríamos estar tentados de clasificar los componentes de la relación metafórica, precisamente, como esos "pensamientos", i. e. elementos semánticos o conceptuales. Aunque es necesario tomar nota del medio lingüístico en tanto soporte de un significado novedoso (a saber, el resultado de esa "activación" simultánea), el protagonismo, no obstante, está en el plano conceptual. Sin embargo, las ideas de tenor y vehículo parecen revelar (aunque en forma quizá algo vaga) una sensibilidad lingüística. En una línea semejante, Black afirma que

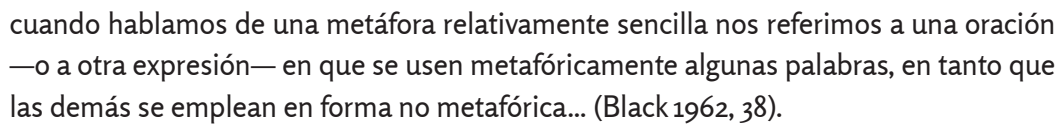

Si nos obligáramos a caracterizar este punto de vista, respecto a la elección del campo de la relación metafórica, "descarnando" los pensamientos en obra del soporte o medio lingüístico que los expresan, el resultado luciría abiertamente forzado. En Richards el énfasis difícilmente pueda disimularse, aun cuando se cuide más la especificación lingüística de los medios expresivos: el par "foco/marco" refina, desde este punto de vista, el precedente par "vehículo/tenor" de su antecesor. Pero, además, la sensibilidad lingüística en Black es inequívoca:

\begin{abstract}
Mi preocupación constante es con las aserciones metafóricas completas y, de manera derivada, con los 'componentes de la aserción' (palabras o frases usadas metafóricamente), solamente en cuanto ocurren en actos de expresión y comunicación específicos y relativamente completos (Black 1979a, 24, trad. nuestra).
\end{abstract}

En síntesis, de tener que priorizar uno de los aspectos, parecería altamente plausible resaltar la dimensión conceptual - aunque tal vez debiera agregarse, lingüísticamente encarnada-. En función de ello, correspondería tal vez representar los relacionales de una forma más compleja, como significados de palabras. Luego, podríamos pensar el par así:

$$
<s(a), s(b)>\in R M,
$$

donde $a, b \in L$, y $s$ es una función cuyo dominio son expresiones lingüísticas y su contradominio, los significados respectivos.

Black no se ocupa de proponer una justificación precisa de la elección de componentes del campo de RM. Es claro en cuanto al origen de la novedad semántica, y, consecuentemente, debe observarse el énfasis conceptual; pero, a la vez, es muy cuidadoso respecto a desprender el fenómeno de su carnadura expresiva. En todos sus textos, el objeto de reflexión es la metáfora lingüística.

Finalmente, la perspectiva de Lakoff y Johnson y TMC, tal como hemos dicho, exhibe una explícita e inequívoca preferencia relacional, así como una manifiesta opción por la naturaleza del campo en cuestión, a saber, conceptos. Al decir de los autores, "la esencia de la metáfora es entender y experimentar un tipo de cosa en términos de otra" (1980, 41, cursivas originales). Hay así una evidente defensa de la pertinencia de la selección del campo, sustentada en el carácter básico y "experiencial" de la metáfora, que incluso trasciende las lenguas históricas específicas. Esta universalidad de las conceptualizaciones y relaciones metafóricas independiza 
radicalmente las mismas de su encarnación particular. Tal énfasis relacionalconceptualista implica $-\mathrm{y}$ así lo entienden teóricos comprometidos con tal perspectiva como Grady $(2007,189)$ y Kövecses $(2002,57$ y sig. $)$ - una suerte de "pluralismo mediático". Si se quisiera retratar, siguiendo el estilo de los casos anteriores, la especificidad de esta perspectiva, podría hacerse de la forma siguiente:

$<\mathrm{a}, \mathrm{b}>\mathrm{ERM}$,

donde $a, b \in C$ y $C$ representa el plano conceptual.

Así planteada, la caracterización de la relación metafórica parece liberalizar el soporte o medio expresivo; el énfasis fundamental se encuentra en la relación entre conceptos. Esta liberalización ha sido recibida como abiertamente positiva por los partidarios de los estudios de la metáfora visual y heterogénea o multimodal. Escribe Charles Forceville: “Un tercer aspecto atractivo de la formulación [se refiere a TMC] es que no especifica el sistema de signos en el cual se logra el acoplamiento metafórico" (Forceville 2008, 462, trad. nuestra).

A partir de los desarrollos previos, las diferentes teorías relacionales estudiadas podrían localizarse, con relación a esta nueva polaridad, del siguiente modo (la ubicación, desde ya, es tentativa):

\begin{tabular}{|c|c|c|c|c|}
\hline $\begin{array}{l}\text { teorías } \\
\text { conceptuales }\end{array}$ & TMC & $\mathrm{R}$ & B & $A$ \\
\hline
\end{tabular}

Figura 8

\section{Teorías relacionales: las características de la relación}

Otra pregunta, casi inmediata, que parece exigible a una teoría relacional es: ¿cuáles son las características o rasgos fundamentales de $R M$ ? $^{12}$ Aquí valdría la pena introducir una distinción. Como es bien conocido, desde el punto de vista matemático, se han identificado en forma rigurosa un conjunto de propiedades de las relaciones. Por ejemplo, entre otras:

$$
\begin{array}{ll}
\text { (Reflexividad) } & \forall x R(x, x) \quad \text { con } x \in D \\
\text { (Simetría) } & \forall x \forall y(R(x, y) \rightarrow R(y, x)) \quad \text { con } x, y \in D \\
\text { (Antisimetría) } & \forall x \forall y(R(x, y) \rightarrow \sim R(y, x)) \quad \text { con } x, y \in D \\
\text { (Transitividad) } & \forall x \forall y((R(x, y) \wedge R(y, z)) \rightarrow R(x, z)) \quad \text { con } x, y, z \in D
\end{array}
$$

Podría pensarse exagerado o impropio este énfasis estructural cuando se trata del tipo de teorizaciones consideradas. Es decir, ¿no es absolutamente ajena a la reflexión sobre la metáfora esta preocupación acerca de las propiedades abstractas de la relación discutida? Si se comienza observando la cuestión desde la perspectiva de aquella teoría que ha asumido más explícita y profundamente su carácter estructural, pueden obtenerse interesantes pistas al respecto. 
Por supuesto, el interés por las propiedades de $R M$ no se agota en identificar meramente propiedades formales. En realidad, el aspecto más interesante a destacar, cuando se estudia la perspectiva cognitiva y especialmente TMC, es el diálogo entre especificación de propiedades sustantivas o de contenido y propiedades formales respecto de $R M$. Tal dinámica, que puede identificarse tempranamente en TMC, es perceptible en la discusión respecto a direccionalidad y estructuración parcial.

En general, los autores que se ubican en esta corriente acentúan la tendencia a estructurar los conceptos más vagos y difusos - como las emociones y nociones abstractas- en términos de conceptos más concretos - es decir, aquellos que están más claramente delineados en función de la experiencia humana-.

Los conceptos menos claramente delineados (y normalmente menos concretos) se entienden parcialmente en términos de los más claramente delineados (y normalmente más concretos) que se fundamentan directamente en nuestra experiencia (Lakoff y Johnson 1980, 150).

Resulta evidente que $R M$, desde tal punto de vista, no puede ser simétrica. La razón es lo que suele denominarse "direccionalidad": existe una diferente cualidad entre el dominio fuente y el dominio meta; el primero es más básico, concreto y primigenio, más próximo desde el punto de vista experiencial que el dominio meta y, por lo tanto, no pueden intercambiarse los roles. Grady (2007) observa que tal direccionalidad asimétrica pone en cuestión la idea de que el uso metafórico sea reflejo de la "semejanza" entre las ideas fuente y meta. ¿Por qué? Porque la semejanza es una relación simétrica: si una cosa es semejante a otra, esta última lo es respecto a la primera. Luego, de ser la semejanza condición suficiente, la relación metafórica resultaría (necesariamente) correcta en ambas direcciones, lo cual no es el caso.

Adviértase que, en este contexto, la opción estructural no solo organiza la perspectiva propia, sino que se transforma en una herramienta para la reconstrucción de otras teorías y, especialmente, su evaluación crítica. Así, por ejemplo, si se necesitara evidencia adicional para respaldar la elección del enfoque aristotélico como caso de teoría relacional, las observaciones de Grady podrían colaborar en tal dirección. Dicho autor interpreta, inequívocamente, la perspectiva aristotélica como relacional. Y la crítica que desarrolla a la misma puede entenderse en clave estructural: la relación metafórica propuesta (al basarse en la semejanza) exhibe propiedades formales incompatibles con las propiedades de la relación metafórica intuitiva. Aunque, por supuesto, la estrategia crítica no se agota en este tipo de ataque, por así llamarlo, formal.

Dado el caso de:

(6) Llegó con la cara radiante.

¿Cuál es la semejanza entre felicidad y luminosidad? La misma falta de similitud es aplicable a la relación entre el frío (físico) y la imperturbabilidad en el famoso ejemplo de Searle (1979):

(7) Sally es un cubo de hielo. 
TMC explica tales proyecciones sobre la base de una motivación experiencial (de la que resultan correspondencias sistemáticas en la experiencia que no tienen por qué estar basadas en la semejanza).

La direccionalidad, lejos de ser una limitación, es valorada por el modelo, puesto que acentúa la razón de ser de las metáforas conceptuales: "la metáfora es el mecanismo principal para que comprendamos los conceptos abstractos y para que ejercitemos el razonamiento abstracto" (Lakoff 1993, 244 , trad. y cursivas nuestras).

La metáfora es uno de nuestros instrumentos más importantes para tratar de entender parcialmente lo que no se puede entender en su totalidad. Nuestros pensamientos, las experiencias estéticas, las prácticas morales y la conciencia espiritual (Lakoff y Johnson 1980, 236).

En tal sentido, TMC sostiene que la mayoría de los conceptos semánticos básicos -y no solo los vinculados a los afectos o los puramente intelectuales - tienen una naturaleza metafórica: tiempo, cantidad, estado, cambio, acción, causa, propósito, medios, modalidad, categoría (Lakoff, op. cit., 212).

La unidireccionalidad no es, sin embargo, irrestricta. Se aplica sin excepciones a las llamadas metáforas primarias (primary metaphors) estudiadas por Grady (1997). Estas recogen los patrones simples (como MÁS ES ARRIBA) que proyectan conceptos perceptuales fundamentales (arriba, abajo, pesado, liviano, adelante, atrás) en otros no directamente perceptuales, pero igualmente fundamentales (difícil, fácil, triste, contento, el pasado). Otro tipo de metáforas, como las denominadas metáforas de imagen (o one-shot images) (Lakoff 1993, Lakoff y Turner 1989), que proyectan no un dominio conceptual con sus diferentes elementos, sino una imagen convencional sobre otra, como en

(8) Mi mujer (...) cuya cintura es un reloj de arena (Breton).

resultan reversibles, y no son las únicas en tal categoría.

La asimetría metafórica se correlaciona directamente con la estructuración parcial. Los conceptos metafóricos destacan y ocultan aspectos del concepto que estructuran. Al permitir centrar la atención en un aspecto (por ejemplo, el lado combativo de una discusión), la metáfora deja afuera otros que no resultan consistentes con ese foco. "Parte de un concepto metafórico no se ajusta ni puede ajustarse a la realidad" (Lakoff y Johnson 1980, 49). De ello se desprende que las metáforas estructuran parcialmente el concepto al cual se aplican y, por ende, proveen un entendimiento parcial del mismo. Adviértase que esta conceptualización permite ser capturada, perfectamente, en términos estructurales. Si se pensara en relaciones que son funcionales, se diría inmediatamente que no son sobreyectivas. No obstante, puesta en forma más general, la situación podría caracterizarse así:

$R M$ es tal que $R M \in F x M, y$, además, existe un $y \in M$ tal que no existe $x \in F$,

donde $F$ representa el dominio fuente y $M$ el dominio meta.

Como se ha ilustrado rápidamente, es posible identificar dos "recorridos" muy netos en la interacción entre dimensión "formal" y dimensión "sustantiva" de la relación metafórica. En el caso de la direccionalidad, partimos del 
plano formal e ilustramos su impacto sustantivo. En el caso de la estructuración parcial, partimos desde la consideración sustantiva y la "traducimos" al plano formal.

Un tema estructural mayor y directamente vinculado con las consideraciones inmediatamente precedentes lo constituye el denominado Principio de Invariancia. Tal principio, introducido por Lakoff y Turner (1989), sostiene que "las proyecciones metafóricas preservan la topología cognitiva (es decir, la estructura de esquemas de imágenes) del dominio fuente, de un modo consistente con la estructura inherente del dominio meta" (Lakoff 1993, 215, trad. nuestra). Kövecses, en su muy conocido manual, lo formula así: “Dado el o los aspectos que participan de una proyección metafórica, proyecta de la fuente a la meta la mayor cantidad de conocimiento que resulte coherente con las propiedades de esquemas de imágenes de la meta" (Kövecses 2002, 103, trad. nuestra).

Con tal principio o hipótesis, se pretende pautar la regularidad de la proyección metafórica: la estructura esquemática del dominio fuente y, principalmente, del dominio meta, no pueden ser violadas. Por otra parte, la estructura inherente del dominio fuente limita automáticamente las posibilidades de proyección. Adviértase que esta preservación estructural del dominio fuente y su compatibilidad estructural con el dominio meta - entendido en el sentido de contradomino, no del conjunto entero de llegada- supone una exigencia mayor. Es decir, hay una especie de coincidencia o conformidad estructural que ofrece así una hipótesis explicativa de la pertinencia y el buen funcionamiento del mapeo metafórico. Dicho de otra forma, el Principio de Invariancia aporta un sustento estructural a la intuición fuerte de que entre ambos conceptos existe no meramente una disímil filiación categorial (el dominio fuente, más básico y concreto; el dominio meta, más general y abstracto), sino que los aproxima un parentesco o semejanza estructural —podría decirse: "salvo proyección"-.

La concepción estructural se refleja en TMC también en otros diversos e importantes rasgos del enfoque, por ejemplo, en la incorporación de la noción de jerarquización inclusiva de metáforas. Un principio fuerte del modelo es la idea de que los conceptos metafóricos son de naturaleza sistemática. Argumentan sus defensores que existe una coherencia en los conceptos, lo que se refleja en relaciones de implicación entre metáforas. La metáfora conceptual EL TIEMPO ES DINERO presente en:

(9) Estoy gastando horas preciosas

implica $^{13}$ EL TIEMPO ES UN RECURSO LIMITADO, que a su vez implica EL TIEMPO ES UN OBJETO VALIOSO. Del mismo modo, EL AMOR ES UN VIAJE que está detrás de:

(10) a. Llegamos a un callejón sin salida

b. Mirá lo lejos que hemos llegado

tiene, por encima, proyecciones metafóricas de más alto nivel, como LA VIDA PLENA ES UN VIAJE y la llamada Metáfora de estructura evento (Lakoff 1993), en la que el dominio meta son los eventos y el dominio fuente es el espacio. Asimismo, como cabría esperar, tal sistematicidad y coherencia estructural no es absoluta. Lakoff y Johnson notan que los conceptos metafóricos pueden no ser consistentes en un cierto nivel de
13. El término "implicación” es utilizado en TMC en una acepción próxima a las inferencias pragmáticas no convencionales de Grice. 
especificidad sin por ello violentar la coherencia metafórica global. Así, por ejemplo, entre las expresiones lingüísticas que testimonian EL AMOR ES UN VIAJE, se encuentran:

\section{(11) a. Nos descarrilamos; \\ b. Estamos estancados;}

las que evidencian una inconsistencia en la medida en que no se acomodan a una única imagen compartida de VIAJE. En (11a) se apela al transporte por vía ferroviaria y en (11b) al transporte por vía marítima. Un desajuste similar puede darse en un nivel jerárquico superior, que es lo que ocurre con la conceptualización del tiempo. Lakoff (1993) sostiene que el tiempo está estructurado de manera dual, en la medida en que coexisten dos metáforas conceptuales inconsistentes dándole forma, por ejemplo:

(12) a. Pronto llegará la primavera.

b. Nos estamos acercando a la primavera.

(12a) y (12b) coinciden en reflejar una metáfora conceptual de nivel elevado: EL PASO DEL TIEMPO ES MOVIMIENTO. Sin embargo, se estructuran sobre la base de dos metáforas distintas de un nivel jerárquico inferior y que heredan la anterior. (12a) se rige por EL PASO DEL TIEMPO ES MOVIMIENTO DE UN OBJETO, metáfora que estipula que el observador está fijo y que es el tiempo el que se mueve con respecto a él. Por el contrario, (12b) supone que el tiempo es la entidad fija y que quien se mueve es el observador, concepción reflejada en EL PASO DEL TIEMPO ES UN MOVIMIENTO SOBRE UN TERRITORIO. Cada una de las metáforas genera implicaciones metafóricas diferentes. La que refiere al objeto permite inferir que el tiempo tiene una velocidad relativa al observador; la que refiere al territorio habilita a pensarlo con una extensión mensurable y con límites definidos.

Al igual que lo que ocurría con la direccionalidad, TMC considera que la inconsistencia es una virtud cognitiva.

Existe una buena razón por la que nuestro sistema conceptual tiene metáforas inconsistentes para un único concepto. La razón es que no existe una metáfora que sea suficiente. Cada una proporciona una cierta comprensión de un aspecto del concepto y oculta otros. Operar solo en términos de un conjunto consistente de metáforas es ocultar muchos aspectos de la realidad. El buen funcionamiento en nuestras vidas diarias parece exigir un constante cambio de metáforas (Lakoff y Johnson 1980, 265).

Estas constataciones son suficientes para sostener que la teoría cognitiva explota al máximo su carácter relacional. A la explicitud de la afirmación se suma, en este caso, la relevancia y coherencia teóricas respecto a la opción estructural, tanto en términos de elección del campo como de propiedades de la relación metafórica.

Por supuesto, no puede identificarse un énfasis y discriminación estructural de idéntico grado en las otras alternativas teóricas revisadas. Si se piensa en Aristóteles, incluso, pueden advertirse algunas tensiones entre opción estructural y desarrollo teórico: dado que el fundamento de $R M$ es la semejanza, entonces parecería que debiera valer, en general, la simetría. Más aún, Aristóteles lo contempla expresamente al momento de caracterizar la metáfora analógica: 
Entiendo por analogía el hecho de que el segundo término sea al primero como el cuarto al tercero; entonces podrá usarse el cuarto en vez del segundo o el segundo en vez del cuarto; y a veces se añade aquello a lo que refiere el término sustituido (Poética, 21, 1457b 17-20).

Pero, como ha sido apuntado por los cognitivos, la simetría no es fácilmente asumible. En particular, para las metáforas que pretende captar TMC.

En defensa de Aristóteles, quizá cabría decir que, al menos en algunos de sus ejemplos, el respeto a la simetría podría sospecharse inocuo. Dicho de una forma directa, el ejemplo (1), La vejez es el ocaso de la vida, bien podría decirse que permite (1') El ocaso es la vejez del día. La reflexividad parece, a su vez, estar implicada por y difícilmente puede entendérsela como compatible con su teoría, pero quizá Aristóteles rechazaría la propia noción de semejanza que puede servir para fundar aquella propiedad formal; es decir, ¿no pensaría el filósofo que $a$ es semejante a $b$, implica que $a$ es distinto de $b$ ? Independientemente de cómo se la entienda, parece indiscutible que la teoría aristotélica, aun siendo relacional, no explota (con el nivel de intensidad en que lo hacen los cognitivos) las propiedades estructurales de la relación. Razones de índole histórica (respecto al desarrollo de la consideración abstracta de las relaciones) resultan aquí obviamente relevantes.

Richards y Black, por su parte, podría decirse que exhiben un mayor grado de articulación entre la teoría y la opción relacional asumida. En tal sentido, sería razonable entender que esta implica representar su propuesta más próxima al polo relacional que Aristóteles. Black, al igual que Richards, da lugar en su reflexión a un espacio algo mayor al análisis estructural de la relación en términos de sus propiedades estructurales. Veamos la situación con más detalle.

En primer lugar, se percibe la diferenciación entre la metáfora y su realización en el discurso. Black distingue ente la "expresión metafórica" (es decir, la ocurrencia específica de una oración en un contexto verbal y no verbal) y el "tema metafórico" que es una abstracción y que "está disponible para su uso repetido, su adaptación y modificación por parte de una diversidad de hablantes o pensadores en cualquier cantidad de ocasiones específicas" (1979a, 24, trad. nuestra).

En segundo lugar, el enfoque es sensible a la direccionalidad: "La metáfora funciona aplicando al asunto principal un sistema de 'implicaciones acompañantes' característico del subsidiario" (1962, 54). Este rasgo, sin embargo, no se traduce claramente en una exigencia de antisimetría, como en el caso de TMC, y tampoco el autor usa tal implicación estructural a los efectos de evaluar otros enfoques teóricos. Asimismo, pueden encontrarse pasajes en que parece establecer una condición estructural propia de TMC: el carácter "no sobreyectivo" de la relación: "La metáfora selecciona, acentúa, suprime y organiza los rasgos característicos del asunto principal al implicar enunciados sobre él que normalmente se aplican al asunto subsidiario" (ibíd.).

En tercer lugar, la estructuración de los dominios implicados se vuelve un asunto explícito en Black (1979a), un texto en el que no casualmente se enfatiza la relación entre metáfora y modelo. Entendiendo la metáfora como "un instrumento para trazar implicaciones fundadas en analogías de estructura percibidas entre dos asuntos que pertenecen a dominios diferentes" (1979a, 31, trad. y cursivas nuestras), Black analiza la composición estructural para el caso de la expresión: 
(13) El matrimonio es un juego de suma cero.

En ella reconoce los elementos intervinientes de los complejos de implicación de una manera muy similar a como lo desarrollarán los cognitivos (cf. ibíd., 28-30). Las ideas de competencia, oponentes y victoria (activas en el juego) dan pie a la proyección de contenidos semánticos equivalentes para el caso del matrimonio. Es decir, siguiendo a Black, tendríamos:

G1) Un "juego" es una contienda;

G2) entre dos oponentes;

$\mathrm{G}_{3}$ ) en el que un jugador puede ganar solo a expensas del otro.

A los efectos del adecuado funcionamiento de la metáfora, las "implicaciones" de los tres contenidos semánticos dependen de la interpretación de juego, oponente y, especialmente, ganar. La propuesta primaria de análisis de Black es:

$\mathrm{M}$ ) Un matrimonio es una batalla sostenida;

$\mathrm{M} 2$ ) entre dos contendientes;

$\mathrm{M}_{3}$ ) en el que las recompensas (¿poder?, ¿dinero?, ¿'satisfacción?) que pueda obtener un contendiente solo se logran a expensas del otro.

Según Black, estas últimas (las implicadas) se entienden literalmente ${ }^{14}$. Es evidente la anticipación de ideas importantes de TMC: la idea de un dominio fuente (juego), un dominio meta (matrimonio) y la centralidad en la economía de la metáfora de la proyección de uno sobre otro, apoyados en la similitud estructural de los mismos. El uso de itálicas en la cita precedente subraya, asimismo, una suerte de protoformulación del Principio de Invariancia.

Black es de la idea de que los complejos de implicación de los asuntos principal y subsidiario no guardan una relación fácilmente etiquetable. Por ende, no solo es imposible fijar con certeza la gama de interpretaciones válidas, sino que también hay que admitir la ambigüedad como una "consecuencia necesaria". Aún así, y teniendo en mente un muestrario más amplio de ejemplos, arriesga un listado de posibilidades de relacionamiento:

las relaciones entre los significados de las palabras clave correspondientes de los dos complejos de implicaciones pueden clasificarse como (a) identidad, (b) extensión, por lo general ad hoc, (c) semejanza, (d) analogía, o (e) lo que puede ser denominado 'acoplamiento metafórico' (donde, como suele ocurrir, la metáfora original implica metáforas subsidiarias) (Black 1979a, 29, trad. nuestra).

Aplicado al ejemplo (13), Black sostiene que el pasaje de G1 a M1 es del tipo (c), mientras que el pasaje de G2 a M2 del tipo (a), al predicarse del matrimonio lo mismo que se predica de un juego de a dos. Por último, en el caso del pasaje de G3 a M3, sería un caso de (b) ya que ganar adquiere un significado extendido.

Aún en un desarrollo en estado embrionario, es evidente la orientación analítica tendiente a sistematizar las posibilidades de proyección.

En cuarto lugar, se podría reconocer en el enfoque de Black una captación de la propiedad de simetría, aunque en una manifestación débil. Ello ocurre cuando comenta casos de metáforas tipificados como complejos, 
en los que el sistema de tópicos acompañantes no resulta operativo como cuando en un poema el autor establece una configuración nueva de implicaciones - o se ve alterado. En tales eventualidades, el autor observa que el asunto principal puede también impactar sobre el asunto subsidiario.

\begin{abstract}
Una vez más, hablar como si el sistema de implicaciones de la expresión metafórica permaneciera inalterable a la afirmación metafórica ha sido una simplificación: la naturaleza de la aplicación que se le pretenda dar ayuda a determinar el carácter del sistema que se vaya a aplicar (...): si bien llamar lobo a un hombre es colocarlo bajo una luz especial, no debemos olvidar que esta metáfora hace que el lobo nos parezca más humano de lo que ocurriría en otro caso (Black 1962, 53).
\end{abstract}

Finalmente, conviene reparar en que, como en el caso de TMC, esta perspectiva abiertamente estructural (en términos relacionales) además de ser aplicable al desarrollo de la teoría propia, opera como una clave para la reconstrucción y análisis de perspectivas ajenas. Black (1962) en su presentación del "enfoque sustitutivo de la metáfora" —es decir aquel propio de quienes sostienen que "las expresiones metafóricas se utilizan en lugar de otras expresiones literales equivalentes a ellas" (1962, 42)—, destaca el carácter relacional de la teoría aristotélica. En tal sentido observa que:

\begin{abstract}
De acuerdo con el enfoque sustitutivo, el foco de la metáfora - la palabra o expresión que se use de modo señaladamente metafórico dentro del marco literal — vale para la comunicación de un significado que podría haberse expresado de modo literal: el autor sustituye L por M y la tarea del lector consiste en invertir la sustitución, sirviéndose del significado literal de M como indicio del también literal L (Black 1962, 43).
\end{abstract}

Pero, en cierta forma, radicaliza la propuesta estructural analizada, interpretándola en clave funcional y, además, generalizándola para el lenguaje figurado (cf. Black 1962, 45).

Algunos autores han señalado que las ideas de Black se inscriben como un antecedente de la perspectiva cognitiva (Beger 2019, 34; de Bustos 2000, 280-2; Díaz 2006, 61; Forceville 2008, 462; Haser 2005, 75; Müller 2008, 126; Thorne 1982, 246, entre otros), pero el enfoque estructural propuesto estimula una atención novedosa hacia determinados aspectos de continuidad entre ambos enfoques y, especialmente, a la lógica de su articulación. Un estudio comparativo minucioso entre ambas concepciones excede largamente los objetivos de este ensayo.

\title{
6. Clasificando teorías: una segunda aproximación
}

Las dos dimensiones consideradas (campo de $R M$, propiedades de $R M$ ) pueden ayudar a esclarecer el nivel de elaboración y coherencia estructural de una teoría. Es decir, el grado en que una teoría desarrolla y refina los desafíos que implica su definición estructural básica. Por supuesto, la apreciación de ambos aspectos está lejos de producir, algorítmicamente, una ubicación precisa de la teoría en cuestión en el eje del diagrama representado en la Figura 1, pero induce (relativamente) un cierto ordenamiento. Adviértase, además, que no son estos los únicos elementos a tomar en consideración. La posición en el eje referido sería una expresión visual de un ordenamiento que surgiría de la consideración, por una parte, de la 
coherencia estructural detectada desde el análisis "externo" y, a su vez, el nivel de justificación y explotación teóricas explícitos en la misma, es decir, una suerte de análisis "interno". Ambos tipos de análisis, en forma primigenia, se han desplegado arriba y permiten una ubicación en el eje referido bien fundamentada (meramente orientadora, pues tal localización, como es obvio, no es producto de una métrica precisa):

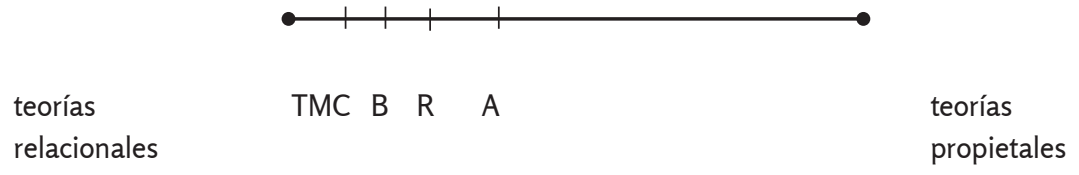

Figura 9

Este ejercicio pretende ilustrar la fecundidad del enfoque propuesto, vía la ejemplificación de un primer análisis de relevantes teorías de la metáfora, en términos de su filiación a la opción relacional, así como de su coherencia estructural y, a la vez, esbozar su comparación. El carácter tentativo y programático de este ensayo no se pretende disimular. La discusión de ciertas similitudes, por ejemplo, entre TMC y la perspectiva interaccionista quizá permita ilustrar el tipo de ganancia que promete el recurso al enfoque propuesto.

\section{Observaciones finales}

Este trabajo expone e ilustra el programa consistente en explorar estructuralmente las diversas teorías de la metáfora en términos de la oposición relación-propiedad. Esta perspectiva arroja como resultado una clasificación (gradualista) entre teorías relacionales y teorías propietales. Los enfoques aristotélicos, interaccionistas y cognitivos se discuten como ejemplos del primer tipo; la propuesta de Davidson, como representante de la segunda clase. Por supuesto, queda abierta la tarea de extender la clasificación, considerando otras teorías de la metáfora y evaluar, consecuentemente, su utilidad.

Dada la importancia histórica y analítica de las teorías relacionales, nos hemos concentrado en este trabajo en analizar los ejemplos emblemáticos arriba referidos. Hemos ofrecido, así, una justificación breve de su adscripción como relacionales y una descripción sucinta de las respuestas que cada una de ellas ofrece a dos desafíos fundamentales: la identificación del campo de la relación metafórica y los rasgos que esta relación exhibe en cada caso. Respecto al primer punto, podría caber la distinción (en virtud de su énfasis en determinados tipos de elementos del campo) entre teorías expresivas y conceptuales. Asimismo, hemos principiado el análisis de su grado de coherencia o sistematicidad, calibradas en términos de su opción estructural. El resultado tentativo de estos esfuerzos nos ha permitido proponer una comparación de tales teorías, visibilizado a través de sus posiciones en el eje de la Figura 9. Como es evidente, podría lograrse una representación que combinara ambos ejes (de las Figuras 8 y 9). Si se ensayara tal representación bidimensional, para las perspectivas relacionales antes discutidas, esta podría lucir aproximadamente así: 


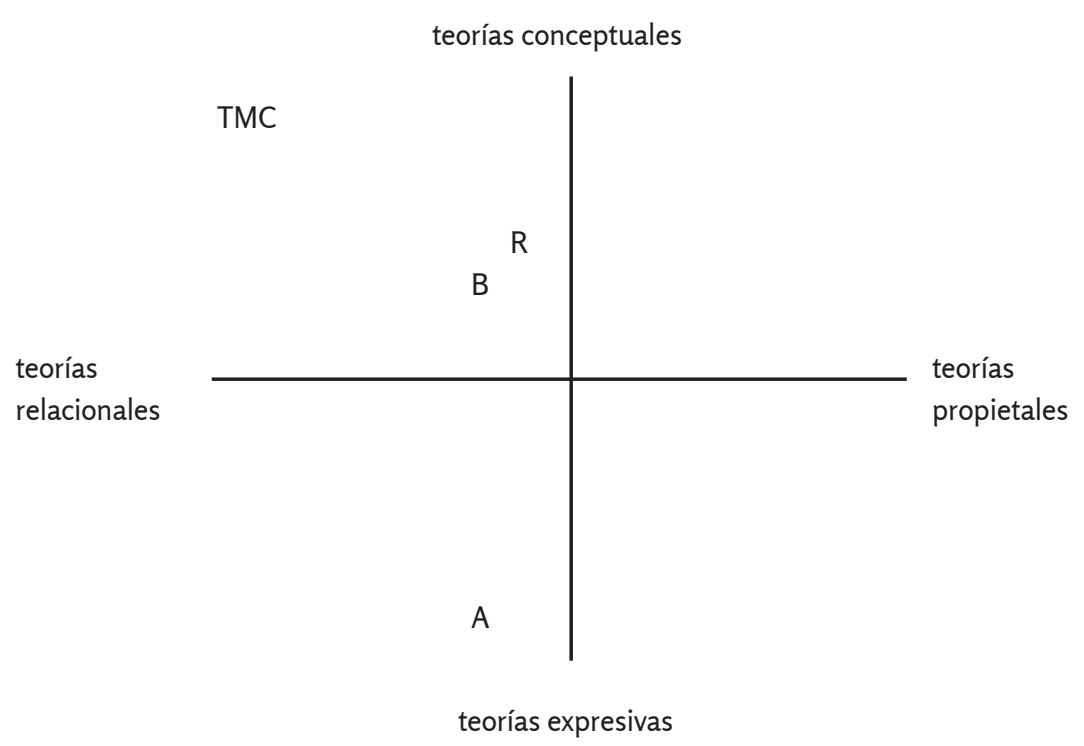

Figura 10

Un trabajo minucioso sobre estas teorías, conjeturamos, puede deparar una más refinada justificación de sus posiciones relativas, así como una mejor comprensión de su estructura. Además, el análisis podría ampliarse incorporando nuevas perspectivas teóricas y, consecuentemente, enriqueciendo el contraste conceptual/expresivo a los efectos de contemplar otras opciones. Esta línea de estudio resulta valiosa, entre otros aspectos, en una orientación ya sugerida: producir una especie de "mapa" estructural del abigarrado y diverso bosque teórico.

El enriquecimiento producido por tal exploración conceptual no depende exclusivamente, sin embargo, del impacto clarificador de la clasificación propuesta; el análisis de la arquitectura interna de las teorías, así como diferentes modalidades de comparación interteórica, resultan labores prometedoras desde la perspectiva estructural. Por ejemplo, revisar los análisis críticos de TMC y, en particular, en tal contexto, examinar las relaciones entre metáfora conceptual y su expresión lingüística puede resultar una tarea fecunda - véase, entre otros, Murphy (1996) y Haser (2005)—. En general, se ha defendido a lo largo de estas páginas una suerte de doble aporte de la sensibilidad estructural (en el sentido específico en que se ha usado aquí el término): a la inteligencia de la economía intrateórica y a la comparación interteórica. La línea esbozada se inscribe con comodidad en esta última dimensión.

En un sentido análogo, las cuestiones siguientes - ya de naturaleza histórica, ya de naturaleza conceptual- permiten ilustrar el potencial de la perspectiva estructural. Dado que las teorías relacionales que se aproximan decididamente al polo expresivo no se encuentran fácilmente en la literatura reciente, ¿podrían ubicarse en la perspectiva más retórica y localizarse su mayor influencia en un cierto contexto histórico determinado? Por otra parte, las teorías relacionales que se aproximan decididamente al polo conceptual pareciera que enfrentan un desafío particular: dado el énfasis fuerte en dicho plano, ¿̇cómo entienden la contribución de la dimensión expresiva al fenómeno metafórico? En forma más precisa, el enfoque cognitivo de la metáfora, cimplica un tratamiento ubicuo radicalmente indiferente al medio 
expresivo? Una investigación futura podría ocuparse de un caso que aparece como especialmente prometedor al respecto: las denominadas "metáforas mixtas" (véase Kimmel 2010 y también Gibbs 2016). Finalmente, si admitimos cierto nivel de impacto del medio expresivo sobre la práctica metafórica, nos enfrentamos a un desafío especialmente interesante: explorar cómo inciden los diversos medios en el fenómeno metafórico (véase, por ejemplo, Carroll 1996 y Forceville 2002 y 2008). 


\section{Q Bibliografía}

》 Aristóteles. 1953. Retórica. Versión de Antonio Tovar. Madrid: Instituto de Estudios Políticos.

» Aristóteles. 1974. Poética de Aristóteles. Versión de Valentín García Yebra, Madrid: Gredos.

"Beger, Anke. 2019. The Role of (Deliberate) Metaphor in Communicating Knowledge in Academic Discourse. Berlín: Peter Lang.

" Black, Max. 1962. "La metáfora”. En Modelos y metáforas, 36-56. Madrid: Editorial Tecnos, 1966.

» Black, Max. 1979a. "More about Metaphor". En Metaphor and Thought, 2da. edition, editado por Andrew Ortony, 19-41. Cambridge: Cambridge University Press, 1993.

» Black, Max. 1979b. “How Metaphors Work: A Reply to Donald Davidson”. En On Metaphor, editado por Sheldon Sacks, 181-192. Chicago: University of Chicago Press.

" Bobes, Carmen. 2004. La metáfora. Madrid: Gredos.

»Carroll, Noël. 1996. “A note on film metaphor”. Journal of Pragmatics, 26: 809-822.

" Davidson, Donald. [1978] 1990. "Qué significan las metáforas". En De la verdad y de la interpretación, 245-262. Barcelona: Gedisa.

» de Azevedo, Andrés. 1997. El lugar de la metáfora. Montevideo: Librería de la Facultad de Humanidades y Ciencias de la Educación.

» de Bustos, Eduardo. 200o. La metáfora. Ensayos transdisciplinares. Madrid: Fondo de Cultura Económica, Universidad Nacional de Educación a Distancia.

" Díaz, Hernán. 2006. "La perspectiva cognitivista". En Metáforas en uso, coordinado por Mariana di Stefano, 41-62. Buenos Aires: Biblos.

" Díaz Tejera, Alberto. 1995. "La metáfora en Aristóteles. Poética 21. 1457 b 7-25”. Emerita, Vol. 63, núm. 1:103-116.

》Diccionario de la lengua española. Real Academia Española y Asociación de Academias de la Lengua Española 23. ․ ed., [versión 23.3 en línea]. Fecha de consulta, 5 de abril de 2019. <https://dle.rae.es>.

"Eco, Umberto. 1990. Semiótica y Filosofía del Lenguaje. Barcelona: Lumen.

" Fauconnier, Gilles y Mark Turner. 2002. The way we think. Conceptual blending and the mind's hidden complexities. Nueva York: Basic Books.

» Femenías, María Luisa. 1998. "El escudo de Dionisio: reflexiones sobre la metáfora según Aristóteles" [en línea] Synthesis, 5:31-43. Fecha de consulta, 7 de abril de 2019. Disponible en http://www.fuentesmemoria.fahce.unip.edu.ar/art_revistas/pr.2707/pr.2707.pdf.

" Forceville, Charles. 2002. "The identification of target and source in pictorial metaphors". Journal of Pragmatics, 34: 1-14.

"Forceville, Charles. 2008. "Metaphor in Pictures and Multimodal Representations". En The Cambridge Handbook of Metaphor and Thought, editado por Raymond Gibbs Jr., 462482. Cambridge: Cambridge University Press.

》 Gambra, José Miguel. 1990. “La metáfora en Aristóteles”. Anuario Filosófico (23): 51-68.

" Gibbs Jr, Raymond W. 1994. The poetics of mind: Figurative thought, language and understanding. Cambridge: Cambridge University Press. 
" Gibbs Jr, Raymond W. ed. 2016. Mixing Metaphor. Amsterdam, Philadelphia: John Benjamins Publishing Company.

»Grady, Joseph E. 1997. "Foundations of meaning: Primary metaphors and primary scenes". Tesis de doctorado, University of California.

" Grady, Joseph E. 2007. “Metaphor”. En The Oxford Handbook of Cognitive Linguistics, editado por D. Geeraerts y H. Cuyckens, 188-213. Nueva York: Oxford University Press.

" Haser, Verena. 2005. Metaphor, metonymy, and experientialist philosophy: challenging cognitive semantics. Berlín: Mouton de Gruyter.

" Kimmel, Michael. 2010. "Why we mix metaphors (and mix them well): Discourse coherence, conceptual metaphor, and beyond". Journal of Pragmatics, 42(1): 97-115. Fecha de consulta, 25 de febrero de 2019. doi:10.1016/j.pragma.2009.05.017

" Kirby, John T. 1997. “Aristotle on Metaphor". The American Journal of Philology, Vol. 118, No. 4. (Winter): 517-554.

» Kittay, Eva Feder. 1987. Metaphor. Oxford: Clarendon Press.

» Kövecses, Zoltán. 2002. Metaphor. A Practical Introduction. Nueva York: Oxford University Press.

"Lakoff, George. 1993. "The contemporary theory of metaphor". En Metaphor and Thought, 2da. edición, editado por Andrew Ortony, 202-251. Cambridge: Cambridge University Press, 1993.

" Lakoff, George y Mark Johnson. 1980. Metáforas de la vida cotidiana. Madrid: Ediciones Cátedra, 1991.

"Lakoff, George y Mark Turner. 1989. More than cool reason. Chicago: The University of Chicago Press.

»Lepore Ernie y Matthew Stone. 2010. "Against Metaphorical Meaning”. Topoi 29: 165180. Fecha de consulta, 23 de febrero de 2019. DOI 10.1007/s11245-009-9076-1

"Marcos, Alfredo. 1997. “The Tension Between Aristotle's Theories and Uses of Metaphor". Studies in History and Philosophy of Science, Vol. 28, No. 1: 123-139.

» Müller, Cornelia. 2008. Metaphors Dead and Alive, Sleeping and Waking. Chicago: The University of Chicago Press.

»Murphy, Gregory L. 1996. “On metaphoric representations”. Cognition 60: 173-204.

» Nogales, Patti D. 1999. Metaphorically Speaking. Standford, California: CSLI Publications,

"Reimer, Marga. 2001. “Davidson on Metaphor”. Midwest Studies in Philosophy, XXV: 142-155.

" Ricoeur, Paul. 1975. La Metáfora Viva. Madrid: Ediciones Europa, 1980.

» Richards, Ivor A. 1936. The Philosophy of Rhetoric. Oxford: Oxford University Press.

" Rorty, Richard. 1987. “Unfamiliar Noises: Hesse and Davidson on Metaphor”. Proceedings of the Aristotelian Society, Supplementary Volumes, Vol. 61:283-296.

» Ross, William D. 1923. Aristotle. Londres: Methuen \& Co. Ltd.

» Searle, John. 1979. "Metaphor". En Expression and Meaning, 76-116. Cambridge: Cambridge University Press.

"Seoane, José. 2003. “Intuiciones y formalismos". Tesis de doctorado, Universidad Nacional de Córdoba, Argentina.

"Seoane, José. 2017. “On mathematical elucidation”. Revista Portuguesa de Filosofía, Vol. $73(3-4): 1405-1422$. 
»Somodi, Gergó. 2014. “A Perlocutionary Account of Metaphors”. Tesis de doctorado. Central European University, Hungría, Budapest.

» Stern, Joseph. 1991. "What Metaphors Do Not Mean”. Midwest Studies in Philosophy, $16: 13-52$.

»Stern, Joseph. 2000. Metaphor in Context. Cambridge, Mass.: The MIT Press.

" Tamba-Mecz, Irène y Paul Veyne. 1979. “Metaphora et Comparaison selon Aristote”. Revue des Études Grecques, tomo 92, fascículo 436-437, enero-junio: 77-98.

» Thorne, James P. 1982. “George Lakoff and Mark Johnson. Metaphors We Live By” Journal of Linguistics, 19, (1): 245-8.

»Vianu, Tudor. 1957. Los problemas de la metáfora. Buenos Aires: Editorial Universitaria de Buenos Aires. 